\title{
Effects of clozapine on behavioral and metabolic traits relevant for schizophrenia in two mouse strains
}

\author{
Jean Mary Zarate \\ Department of Neurology and Neurosurgery \\ McGill University, Montréal
}

May 2002

A thesis submitted to the Faculty of Graduate Studies and Research in partial fulfillment of the requirements of the degree of Master of Science in Neurological Sciences.

(C) Jean Mary Zarate, 2002 
National Library

of Canada

Acquisitions and Bibliographic Services

395 Wellington Street Ottawa ON K1A ON4

Canada
Bibliothèque nationale

du Canada

Acquisitions et

services bibliographiques

395, rue Wellington

Ottawa ON K1A ON4

Canada
The author has granted a nonexclusive licence allowing the National Library of Canada to reproduce, loan, distribute or sell copies of this thesis in microform, paper or electronic formats.

The author retains ownership of the copyright in this thesis. Neither the thesis nor substantial extracts from it may be printed or otherwise reproduced without the author's permission.
L'auteur a accordé une licence non exclusive permettant à la Bibliothèque nationale du Canada de reproduire, prêter, distribuer ou vendre des copies de cette thèse sous la forme de microfiche/film, de reproduction sur papier ou sur format électronique.

L'auteur conserve la propriété du droit d'auteur qui protège cette thèse. $\mathrm{Ni}$ la thèse ni des extraits substantiels de celle-ci ne doivent être imprimés ou autrement reproduits sans son autorisation. 


\section{TABLE OF CONTENTS}

ABSTRACT

RÉSUMÉ

ACKNOWLEDGMENTS

INTRODUCTION

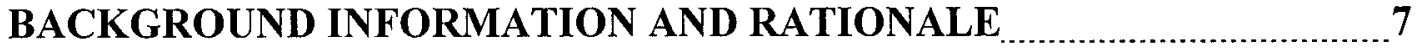

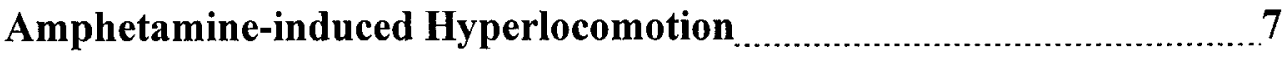

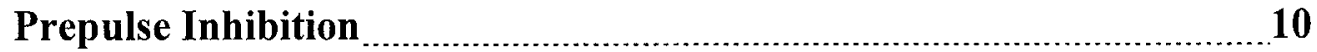

Using Behavioral Paradigms in Animals to Model Antipsychotic

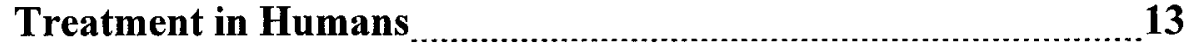

Weight Gain $\ldots$

HYPOTHESES AND DESIGN RATIONALE

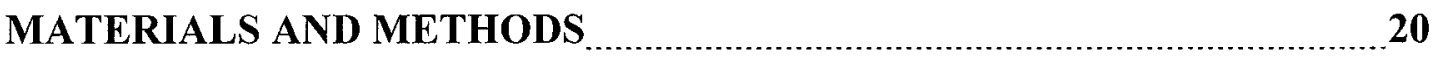

Experiment 1 $\ldots \ldots \ldots \ldots$

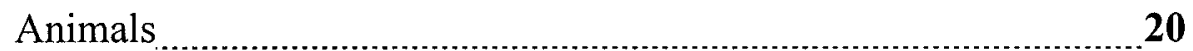

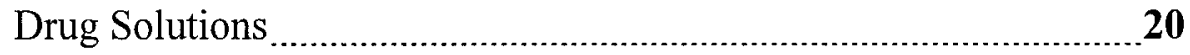

Prepulse Inhibition $\quad 2 \ldots$

Locomotor Testing

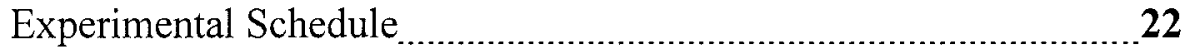

Experiment 2

Animals 
TABLE OF CONTENTS (continued)

Drug Solutions

Experimental Procedure

Data Analysis

RESULTS

Experiment 1: Male mice, 6-8 weeks old 27

Prepulse Inhibition: 3 days 27

Prepulse Inhibition: 21 days. 28

Amphetamine-induced Hyperlocomotion: 4 days. 29

Amphetamine-induced Hyperlocomotion: 22 days 31

Weight Gain 32

Experiment 2: Weight gain in female mice, 9-10 weeks old 33

DISCUSSION 35

TABLE AND FIGURES

Table 1: Effects of short-term clozapine treatment on startle responses

Figure 1: Short-term clozapine treatment effects on prepulse inhibition with a prepulse of $75 \mathrm{~dB}$

Figure 2: Short-term clozapine treatment effects on prepulse inhibition with a prepulse of $80 \mathrm{~dB}$

Figure 3: Amphetamine-induced hyperlocomotion after short-term clozapine treatment 
TABLE OF CONTENTS (continued)

Figure 4: Short-term clozapine treatment effects on peaks of amphetamine-induced locomotor activity.

Figure 5: Amphetamine-induced hyperlocomotion after long-term

clozapine treatment 46

Figure 6: Weight in male $\mathrm{A} / \mathrm{J}$ and $\mathrm{C} 57 \mathrm{BL} / 6 \mathrm{~J}$ mice during long-term clozapine treatment

Figure 7: Treatment effects on cumulative weight changes in female $\mathbf{A} / \mathbf{J}$ mice 48

Figure 8: Treatment effects on cumulative weight changes

in female C57BL/6J mice 49

REFERENCE LIST 50 


\section{ABSTRACT:}

Patients with schizophrenia exhibit considerable variability in therapeutic and metabolic (i.e. weight gain) responses to clozapine, an atypical antipsychotic medication. We treated the $\mathrm{C} 57 \mathrm{BL} / 6 \mathrm{~J}$ and $\mathrm{A} / \mathrm{J}$ inbred mouse strains with clozapine for 21 days to assess weight gain and behavioral response variations in two models of drug response in schizophrenia (prepulse inhibition and amphetamine-induced hyperlocomotion). If

detected, between-strain differences may be partially due to genetic factors that can be subsequently mapped using quantitative genetic approaches.

Clozapine increased prepulse inhibition and decreased amphetamine-induced hyperlocomotion after three days of treatment in both the $\mathrm{C} 57 \mathrm{BL} / 6 \mathrm{~J}$ and $\mathrm{A} / \mathrm{J}$ strains. These effects were not observed after 21 days. Clozapine did not induce significant weight gain in either strain. Since these strains do not respond to clozapine treatment differently, the identification of more suitable strains for further genetic analyses of response variations may be warranted. 


\section{RÉSUMÉ:}

Les patients atteints de schizophrénie montrent une variabilité considérables dans leurs réponses thérapeutique et métabolique (gain de poids) à la clozapine, un antipsychotique atypique. Nous avons traité deux lignées consanguines de souris, $\mathrm{C} 57 \mathrm{BL} / 6 \mathrm{~J}$ et $\mathrm{A} / \mathrm{J}$, pendant 21 jours et évalué leur gain de poids et leur réponse comportementale selon deux modèles de réponse aux neuroleptiques (l'inhibition du réflexe de sursaut -IRS- et l'inversion de l'hyperlocomotion induite par l'amphétamine IHIA-). Toute différence détectée entre les deux lignées pourrait être due, au moins partiellement, à des facteurs génétiques pouvant être précisés ultérieurement.

La clozapine a augmenté l'IRS et a induit une IHIA dans les deux lignées de souris après trois jours de traitement. Aucun effet n'a été observé après 21 jours. La clozapine n'a pas induit de prise de poids. Vu la similarité de la réponse à la clozapine dans les deux lignées, l'identification d'autres lignées présentant des réponses différentes est indiquée. 


\section{ACKNOWLEDGMENTS:}

I would like to thank my co-supervisors, Patricia Boksa, Ph.D. and Ridha Joober, M.D., $\mathrm{Ph}$.D. for their excellent supervision and assistance in the preparation of the experiments and this thesis. Thank you also for your endless support, patience and understanding over these last two years.

I would also like to thank Trino Baptista, M.D., Ph.D. for his collaboration and his willingness to help me whenever it was needed.

Thank you to my Advisory Committee members, Drs. Joseph Rochford and Edward Fon, for their assistance over the last two years.

I also thank Jesse Carlevaris, Yves Gingras and Ying Zhang for their expert and technical assistance.

Finally, I would like to thank my family for their loving encouragement and support, which often helped me get through some stressful situations.

This work was supported by grants to Ridha Joober and Patricia Boksa from RGS Genome Inc., the National Alliance for Research on Schizophrenia and Depression (NARSAD) and the Canadian Institutes of Health Research (CIHR). 


\section{INTRODUCTION}

For the century that schizophrenia has been recognized as a psychiatric disorder, its clinical heterogeneity has prevented doctors and scientists from determining its precise definition and etiology. Symptoms seen in schizophrenia include auditory hallucinations, delusions, thought disorders, blunted affect and social withdrawal. Unfortunately, some of these symptoms are also associated with other neurological and psychiatric disorders. Therefore, the highly variable presentation of symptoms in schizophrenia poses a daunting challenge for both diagnosis and treatment of this debilitating illness.

Treatment with typical antipsychotic drugs (e.g. chlorpromazine, haloperidol) results in a variable improvement of psychotic symptoms (Brenner et al., 1990). By virtue of their blockade of $\mathrm{D}_{2}$ receptors, typical antipsychotics primarily ameliorate positive symptoms (e.g. hallucinations, delusions) that may be caused by hyperdopaminergic transmission (Laruelle and Abi-Dargham, 1999). Negative symptoms like social withdrawal are affected much less by typical antipsychotic treatment (Kennedy et al., 2000). Unfortunately, the antidopaminergic activity of typical antipsychotic drugs can also elicit extrapyramidal symptoms and tardive dyskinesia in a substantial proportion of patients. In addition, treatment with typical antipsychotic medication can be partially or totally ineffective in approximately $30-60 \%$ of schizophrenic patients (Cortese, 2002).

About one-third of these refractory patients respond to clozapine, the prototype of atypical antipsychotic drugs (Cortese, 2002). Clozapine possesses a much broader pharmacological profile than typical antipsychotics. It has a relatively weak affinity for the $\mathrm{D}_{2}$ receptor, which may partially explain its smaller propensity to induce 
extrapyramidal symptoms and tardive dyskinesia than typical antipsychotics. Its actions on the serotonergic, adrenergic, histaminergic, and muscarinic transmitter systems also allows for the amelioration of negative symptoms (Buchanan, 1995). Unfortunately, this broader profile also elicits other serious side effects, such as agranulocytosis and significant weight gain (Jann, 1991; Jann et al., 1993; Buchanan, 1995). Furthermore, antipsychotic-induced weight gain is a major reason for non-compliance with treatment (Fleischhacker et al., 1994). However, some studies suggest that weight gain is a necessary side effect of atypical-antipsychotic treatment (Wetterling and Mussigbrodt, 1999) and may even be positively correlated to symptom amelioration (Leadbetter et al., 1992).

Among clozapine-treated patients, therapeutic responses and side effect profiles vary considerably; only up to $60 \%$ of these patients respond to treatment (Arranz et al., 2000; Masellis et al., 1998; Rietschel et al., 1997). In addition to inter-individual differences in clozapine responses, many studies suggest that these responses vary between several ethnic groups (Emsley et al., 2002; Frackiewicz et al., 1997; Masellis et al., 1998; Turbay et al., 1997). These observations suggest that responses to clozapine treatment may be, at least in part, genetically controlled. Some clinical studies have reported the implication of allelic variants of certain receptor genes in the modulation of therapeutic responses to clozapine and resulting side effects, such as agranulocytosis and weight gain (Detterling and Cascorbi, 2001; Masellis et al., 1998; Rietschel et al., 1997; Turbay et al., 1997). Unfortunately, methodological issues such as treatment length and clinical measurements of symptom amelioration often confound these findings. To overcome these obstacles, animal models can be used; in animal experiments, 
experimental variables like those listed above can be controlled. Therefore, in this study, we used two inbred mouse strains to assess behavioral and metabolic (i.e. weight gain) responses to clozapine treatment. Should strain differences exist, they may be partially due to genetic factors, which can be further investigated using quantitative genetic approaches. 


\section{BACKGROUND INFORMATION AND RATIONALE}

Although clinical studies have made great advances in determining potential genetic factors responsible for variations in clozapine response, their findings are often incongruent. These inconsistencies arise from differences in treatment length, symptom measurement, and other methodological issues. To complement these clinical studies, animal experiments can be conducted. In animal studies, the advantage of controlled experimental variables offers a more rigid and thorough investigation of underlying factors for varying clozapine responses.

\section{Amphetamine-induced Hyperlocomotion:}

Due to the clinical heterogeneity of schizophrenia, finding a comprehensive animal model of the illness is a challenging task. Rather, many earlier animal studies in schizophrenia have used models based on abnormalities in neurotransmission that may underlie the causes of schizophrenia (Kilts, 2001). A prevailing hypothesis suggests that excess dopaminergic transmission in mesolimbic brain regions may cause some of the positive symptoms of schizophrenia. This "dopamine hypothesis" arose from the fact that clinically effective typical antipsychotics exert antagonistic actions upon $D_{2}$ receptors. Further support for this theory came from neuroimaging studies that revealed slightly higher $D_{2}$ receptor densities in the brains of schizophrenic patients when compared to normal controls (Laruelle, 1998). More importantly, amphetamine administration, which increases dopamine transmission, resulted in more synaptic dopamine availability in schizophrenic patients when compared to healthy controls 
(Laruelle et al., 1999). Clinically, amphetamine can exacerbate symptoms in schizophrenic patients and elicit behaviors that mimic some positive symptoms (e.g. delusions, hallucinations) of schizophrenia in normal humans (Laruelle, 1998; Snyder, 1973). In rodents, treatment with low doses of amphetamine elicits amphetamineinduced hyperlocomotion (Snyder, 1973). Most animal studies utilize low doses of amphetamine because they specifically target mesolimbic dopaminergic pathways, which are putatively implicated in the genesis of positive symptoms. Thus, amphetamineinduced hyperlocomotion in rodents can be used as a behavioral model for positive symptoms of schizophrenia.

Amphetamine-induced hyperlocomotion may have construct validity as a model for some neurochemical changes that possibly underlie positive symptoms of schizophrenia. This paradigm has been used many times as a model to test proposed factors that may increase vulnerability to schizophrenia. For example, two studies revealed that birth complications enhanced amphetamine-induced hyperlocomotion, thus providing support for the implication of obstetrical complications in the pathogenesis of schizophrenia (El-Khodor and Boksa, 1998; Vaillancourt and Boksa, 1998). A subsequent experiment determined that birth complications differentially affected amphetamine-induced hyperlocomotion in three rat strains, suggesting a genetic predisposition to the effects of birth insults (Berger et al., 2000). This paradigm has also been used in lesion studies to test neural substrates possibly involved in the development of schizophrenia. One such study determined that lesioning the rat ventral hippocampus shortly after birth increased amphetamine-induced hyperlocomotion when the rats reached early adulthood (Lipska et al., 1993). A similar enhancement resulted from 
lesions in the adult medial prefrontal cortex (Lipska et al., 1992). The investigators concluded that lesions in the neonatal ventral hippocampus might enhance dopaminergic transmission in mesolimbic pathways, thus supporting the implication of mesolimbic dopaminergic pathways in the pathology of schizophrenia (Lipska et al., 1993).

Amphetamine-induced hyperlocomotion may also have predictive validity for determining antipsychotic properties of many compounds. In humans, antipsychotic drugs with antidopaminergic properties alleviate some of the positive symptoms seen in schizophrenia. Given that amphetamine-induced hyperlocomotion is considered a behavioral model for some positive symptoms, any compound that reduces amphetamineinduced hyperlocomotion may be a potential antipsychotic drug. Clinically effective typical and atypical antipsychotic drugs have been demonstrated to reduce amphetamineinduced hyperlocomotion (Sams-Dodd, 1998). This behavioral paradigm has also been used to test dopaminergic (Jackson et al., 1994; Corbin et al., 2000), serotonergic (Corbin et al., 2000; Kehne et al., 1996; Rigdon and Weatherspoon, 1992), glutamatergic (KarczKubicha et al., 1999) and muscarinic (Stanhope et al., 2001) compounds for antipsychotic potential.

While experiments have demonstrated some validity for the use of amphetamineinduced hyperlocomotion to model some positive symptoms of schizophrenia, this paradigm has important limitations. The dopamine hypothesis, in which this paradigm is rooted, does not explain the genesis of negative symptoms. Furthermore, following amphetamine challenge in schizophrenic subjects, the resulting increase in synaptic release of dopamine is observed only during the recurrence of psychotic symptoms (Laruelle and Abi-Dargham, 1999). Therefore, this abnormality in dopaminergic 
transmission may be a phasic characteristic of the psychotic state rather than a tonic landmark of schizophrenia. Accordingly, amphetamine-induced hyperlocomotion may model only some positive symptoms seen during psychotic stages in schizophrenia.

\section{Prepulse Inhibition:}

Within the last decade, an increasing number of studies have focused more on thought processes that are afflicted in schizophrenia, rather than just on abnormalities in neurotransmission. Schizophrenic patients have difficulty filtering out irrelevant thoughts or external stimuli, a process commonly referred to as gating. These gating deficits are believed to be the underlying cause of sensory flooding and cognitive fragmentation in schizophrenic patients (Braff and Geyer, 1990). A phenomenon known as prepulse inhibition is considered as a physiological measure of sensorimotor gating. Briefly, prepulse inhibition occurs when a mild stimulus (i.e. the prepulse), presented 30500 milliseconds before a strong, startling event, reduces the startle response to that event, regardless of the modalities of the prepulse and startling stimulus (e.g. tactile, auditory, visual) (Hoffman and Ison, 1980; Swerdlow and Geyer, 1998). The prepulse activates a cortico-striato-pallido-thalamic circuit, which inhibits the pontine startle circuit, thereby reducing responses to subsequent stimuli that are presented within a 30 500-millisecond time window (Braff et al., 2001). Imaging studies have reported that schizophrenic patients possess abnormalities in some of the same brain substrates that regulate prepulse inhibition (Swerdlow and Geyer, 1998). Numerous studies have demonstrated that persons with schizophrenia or schizophrenia-spectrum disorders exhibit deficits in both prepulse inhibition and gating processes (Braff and Geyer, 1990; 
Braff et al., 2001; Geyer et al., 1990; Swerdlow and Geyer, 1998). Therefore, abnormalities in this prepulse circuit may elicit deficits in both prepulse inhibition and gating mechanisms.

Prepulse inhibition is a behavior that is readily tested in any species and thus provides an excellent animal model for symptoms of schizophrenia that could be putatively related to gating deficits. Investigators have again turned to neurotransmission and neurodevelopmental theories to consolidate the construct validity of this model for gating deficits in schizophrenia. By disrupting prepulse inhibition in animals, investigators can model both deficient prepulse inhibition and gating difficulties observed in schizophrenia. Some rodent studies have observed reduced prepulse inhibition after lesioning brain regions that are implicated in the pathogenesis of schizophrenia, such as lateral and medial prefrontal cortex (Bubser and Koch, 1994; Lacroix et al., 2000; Swerdlow et al., 1995) and ventral hippocampus (Lipska et al., 1995; Swerdlow et al., 1995). Other studies have found that raising rodent pups in isolation can also substantially reduce prepulse inhibition (Varty and Higgins, 1995; Depoortere et al., 1997; Swerdlow and Geyer, 1998). Pharmacological studies have shown that administration of dopamine agonists such as apomorphine and $d$-amphetamine can disrupt prepulse inhibition (Geyer et al., 1990). Due to the involvement of serotonergic and glutamatergic transmission in the startle gating circuitry, $5-\mathrm{HT}_{2}$ agonists and noncompetitive NMDA antagonists can also interfere with prepulse inhibition (Varty and Higgins, 1995). Both typical and atypical antipsychotic drugs reverse these pharmacological- and isolation-induced disruptions in prepulse inhibition (Depoortere et al., 1997; Geyer et al., 2001; Hoffman and Donovan, 1994; Rigdon and Viik, 1991; 
Swerdlow and Geyer, 1993; Swerdlow et al., 1994; Swerdlow and Geyer, 1998; Varty and Higgins, 1995). Since these compounds are also effective in treating schizophrenia, disruptive prepulse inhibition has predictive validity as a model for some aspects of schizophrenia.

Pharmacologically disrupted prepulse inhibition has also revealed variations in responses to drug treatment. While Swerdlow and Geyer (1993) determined that clozapine successfully reversed apomorphine-disrupted prepulse inhibition, the use of a different rat strain by Varty and Higgins (1995) possibly prevented the replication of these results. Collaboration between these investigators revealed differential responses to both clozapine and apomorphine - Wistar rats were less sensitive to the effects of both drugs than Sprague-Dawley rats (Swerdlow et al., 1998).

The strain difference in clozapine responses found in this prepulse inhibition study is consistent with observed variations in clozapine responses among schizophrenic patients. Clozapine-induced reversal of disrupted prepulse inhibition in different rodent strains could reveal possible genetic underpinnings of varying clozapine responses. Unfortunately, the interaction between clozapine and apomorphine may present a confounding element when determining the underlying causes of clozapine response variations. Therefore, other methods of prepulse-inhibition disruption must be utilized. Advances in genetics and mouse breeding have resulted in several inbred mouse strains with strain-specific characteristics. Comparison studies have determined that several of these inbred mouse strains exhibit significantly different levels of prepulse inhibition (Bullock et al., 1997; Paylor and Crawley, 1997). Thus in our study, rather than trying to 
correct a drug-induced disruption of prepulse inhibition, we used clozapine to potentiate low prepulse inhibition levels that are presumably genetic in origin.

\section{Using Behavioral Paradigms in Animals to Model Antipsychotic Treatment in Humans:}

As mentioned before, many animal studies have assessed the effects of antipsychotic compounds by using behavioral paradigms such as amphetamine-induced hyperlocomotion and prepulse inhibition. Importantly, these studies tested drug effects after only a single acute administration of the drug. However, typical and atypical antipsychotic drugs do not ameliorate schizophrenic symptoms until after two to three weeks of treatment (Freed, 1988). Sams-Dodd (1998) treated rats with clozapine or haloperidol for 21 days to model long-term treatment in humans, and he assessed drug effects after 3 and 21 days of treatment with amphetamine-induced hyperlocomotion. He found that both drugs reduced hyperlocomotion at both time points. In contrast, two later studies failed to find reversal of dopamine-agonist-induced behaviors after long-term treatment (21 days or more) with antipsychotics, although acute and subchronic (3-7 days) treatments were effective (Andersen and Pouzet, 2001; Martinez et al., 2000). Our experiments will try to determine whether short-term antipsychotic treatment, as opposed to long-term treatment, sufficiently induces behavioral changes that model therapeutic response in mice.

\section{Weight Gain:}

Treatment of schizophrenia with atypical antipsychotic compounds, such as clozapine and olanzapine, provides several advantages over treatment with typical 
antipsychotic medication. Atypical antipsychotics exert weaker antagonistic actions on $D_{2}$ receptors, so they pose a lesser risk of developing extrapyramidal symptoms and tardive dyskinesia than typical antipsychotic drugs. The broader pharmacological profiles of these second-generation antipsychotics also allow them to target both positive and negative symptoms of schizophrenia, whereas typical antipsychotics primarily treat positive symptoms (Cortese, 2002).

While atypical antipsychotics offer such advantages, they also present an important side effect - significant weight gain. Comparison studies have shown that atypical antipsychotic drugs induce more weight gain than typical antipsychotics (Allison et al., 1999; Wetterling and Mussigbrodt, 1999) by virtue of their actions at serotonergic and histaminergic receptors (Baptista et al., 2001). Antipsychotic-induced weight gain is considered a major reason for non-compliance with treatment (Fleischhacker et al., 1994). Moreover, weight gain and obesity are associated with coronary heart disease, diabetes, hypertension, and other serious illnesses (Allison et al., 1999; Blin and Micallef, 2001). Despite the health risks that antipsychotic-induced weight gain poses, it may reflect an important biological result that may be linked to the therapeutic activity of antipsychotic treatment. Therefore, antipsychotic-induced weight gain can be viewed as a sign of treatment compliance (Wetterling and Mussigbrodt, 1999). In fact, Leadbetter and colleagues (1992) found that profound weight gain positively correlated with significant improvements in schizophrenic symptoms, and they concluded that weight gain might be somehow related to drug efficacy. However, the correlation between weight gain and clinical response has yet to be confirmed. 
Comparisons among different atypical antipsychotic compounds revealed that clozapine was among the drugs that caused the greatest weight gain (Allison et al., 1999; Taylor and McAskill, 2000; Wetterling and Mussigbrodt, 1999). Studies have shown that clozapine-induced weight gain differs among individuals, which suggests an underlying genetic predisposition for this trait (Basile et al., 2001; Theisen et al., 2001). Thus far, only one clinical study has thoroughly examined genetic variations that may be involved in clozapine-induced weight gain, but unfortunately, sample size and length of treatment prevented any definitive conclusions (Basile et al., 2001). Therefore, in a controlled animal experiment, we observed clozapine-induced weight gain in two inbred mouse strains. Significant strain differences in this trait may suggest underlying genetic effects, which can be later examined with quantitative genetic approaches. 


\section{HYPOTHESES AND DESIGN RATIONALE:}

Given the preceding information, the following experiments were designed to investigate three hypotheses:

1) Behavioral and metabolic responses to clozapine treatment may be partially under genetic control. If between-strain differences in these traits are observed, we will subsequently investigate these differences by using quantitative trait loci (QTL) approaches, specifically the recombinant congenic strains derived from the $A / J$ and $\mathrm{C} 57 \mathrm{BL} / 6 \mathrm{~J}$ mouse strains.

2) Under clozapine treatment, weight gain may be correlated with behavioral responses that are often used as indices of therapeutic response in humans.

3) Short-term treatment with clozapine in mice may be sufficient to induce behavioral changes that may model therapeutic response.

Behavioral and metabolic responses to clozapine are measurable or quantitative traits that are most likely controlled by several genes. Several approaches can be taken to discover genes that may govern a quantitative trait, including gene mapping with the use of recombinant congenic mouse strains. Recombinant congenic mouse strains are derived from controlled breeding of two inbred mouse strains that differ greatly in the phenotypes or traits of interest. Two rounds of backcrossing of F1 offspring with either of the parental strains, followed by 18-30 rounds of inbreeding, result in mouse strains that contain an average of $12.25 \%$ of one strain's genetic makeup introduced onto the background of the other strain (Démant and Hart, 1986). Essentially, the relevant genes 
are separated and distributed among the different recombinant congenic strains. Each gene can therefore be tested in the individual strains for the phenotypes of interest (Groot et al., 1992). Recombinant congenic mouse strains have already been used to find genes implicated in colon cancer susceptibility (van Wezel et al., 1999; Moen et al., 1996; Moen et al., 1991), T-lymphocyte responses (Lipoldova et al., 1995), and malaria susceptibility (Fortin et al., 2001a).

We had recombinant congenic strains derived from the $\mathrm{A} / \mathrm{J}$ and $\mathrm{C} 57 \mathrm{BL} / 6 \mathrm{~J}$ inbred mouse strains at our disposal (Fortin et al., 2001b). We recently used these strains to find potential genes that govern prepulse inhibition (Joober et al., 2002, in press). Before we could use this powerful tool to find genes that may modulate clozapine response, we assessed behavioral and metabolic responses to clozapine in the two parental strains. Observed parental-strain differences would justify the use of similar experiments on their recombinant congenic strains to map potential genes involved in these traits (see Démant and Hart, 1986).

In the first experiment, we treated $\mathrm{C} 57 \mathrm{BL} / 6 \mathrm{~J}$ and $\mathrm{A} / \mathrm{J}$ mice with either $2 \mathrm{mg} / \mathrm{kg}$ or $4 \mathrm{mg} / \mathrm{kg}$ of clozapine for 22 days. Preliminary dose response tests revealed that these were optimal doses for our procedures. Similarly, to determine the appropriate dose of amphetamine for locomotor testing, we performed preliminary experiments with two doses of amphetamine $(2.5 \mathrm{mg} / \mathrm{kg}$ and $5 \mathrm{mg} / \mathrm{kg})$. These tests revealed that the lower amphetamine dose did not sufficiently elevate locomotion in mice, while the higher dose increased locomotor activity without inducing stereotypic behavior in the mice (e.g. sniffing, rearing, gnawing). Since C57BL/6J mice experience progressive hearing loss after approximately 2 months of age (McCaughran Jr et al., 1999; Willott, 1986; Li and 
Borg, 1991), we used six- to eight-week-old mice to take full advantage of the intact C57BL/6J auditory system for prepulse inhibition testing.

The mice were tested for prepulse inhibition and amphetamine-induced hyperlocomotion after both 3 and 21 days of treatment. Between the behavioral testing sessions, we monitored weight gain for 14 consecutive days. Results from this experiment revealed significant weight loss after the first testing session in all mice, regardless of treatment type and strain. The two-week period between tests allowed the mice to regain the weight lost due to stress from the first set of behavioral tests.

Subsequently, we designed our second experiment to observe pure weight gain without the stress of behavioral testing.

Previous studies have shown that female rodents are more prone to substantial weight gain under antipsychotic treatment (Baptista et al., 1987). Moreover, other studies have shown that risperidone, another atypical antipsychotic, can also induce significant weight gain (Penn et al., 1996; Wetterling and Mussigbrodt, 1999). Therefore, in collaboration with a different set of experiments, we treated female mice with either risperidone or clozapine to determine which drug induced more weight gain. We also changed other parameters of the experiment to maximize weight gain due to antipsychotic treatment. We tested the mice at an older, post-pubertal age of 9-10 weeks to ensure that weight gain would not be susceptible to fluctuating hormone levels during puberty (Baptista et al., 1988). All injections were administered subcutaneously, rather than intraperitoneally, to prolong the half-life of the drug; this allows the drug to exert its effects before its breakdown in the liver. Additionally, drug absorption is much slower in the skin capillaries than in the peritoneal cavity, which ensures that the drug will last 
longer between treatments (Benet et al., 1996). To keep more constant levels of the drug in the blood, injections were given twice a day. Also, to remove extra stress due to constant manipulation, we recorded weights only every 3-4 days instead of on a daily basis. 


\section{MATERIALS AND METHODS}

\section{Experiment 1:}

Animals:

We used a total of 122 male $\mathrm{C} 57 \mathrm{BL} / 6 \mathrm{~J}$ and A/J mice, aged 6-8 weeks, in this experiment (RGS Genome Inc., Montreal, Canada). They were housed in groups of 4-12 per cage in an animal room kept at $20-22{ }^{\circ} \mathrm{C}$, with a relative humidity of $40 \%$ and a 12 hour light cycle (lights on $0800-2000 \mathrm{~h}$ ). Throughout their stay, mice had free access to standard mouse chow and water. Mice were allowed a minimum of 3 days to acclimatize to the new facility before behavioral testing.

\section{Drug Solutions:}

Clozapine (mol. wt. 326.8, Alexis Biochemicals) was dissolved in $5 \mathrm{~N} \mathrm{HCl}$, adjusted to $\mathrm{pH} 7$ with $0.1 \mathrm{~N} \mathrm{NaOH}$, and brought to final volume with $0.9 \%$ sterile saline. Vehicle solution consisted of $0.9 \%$ sterile saline with the same amount of $5 \mathrm{~N} \mathrm{HCl}$ used to dissolve the clozapine and brought to a final $\mathrm{pH}$ of 7 with $0.1 \mathrm{~N} \mathrm{NaOH}$. Dexamphetamine sulphate was dissolved in $0.9 \%$ sterile saline. All injections were delivered in a volume of $10 \mathrm{~mL} / \mathrm{kg}$.

\section{Prepulse Inhibition:}

Two identical SR-LAB startle response chambers were used for startle testing (San Diego Instruments, San Diego, CA, USA). Each sound-attenuated and ventilated chamber contained a Plexiglass cylinder whose inner diameter $(3.8 \mathrm{~cm})$ and length $(6.5$ 
$\mathrm{cm})$ restricted movement. The cylinder sat on top of a piezoelectric transducer, which detected vibrations caused by the mouse's movements. Regular calibrations were performed to maintain consistent recording sensitivity between chambers and across testing days. An SR-LAB Control 281 sound generating system produced all acoustic stimuli. A Radio Shack digital sound level meter (A scale) was used to calibrate sound intensity within the chambers. A microcomputer control unit controlled the timing and presentation of acoustic stimuli; this control unit also digitized and stored startle responses to the stimuli. Startle amplitude, measured in arbitrary units, was determined by the average of 65 readings taken at one-millisecond (msec) intervals, beginning at stimulus onset.

Startle testing took place between $0900 \mathrm{~h}$ and $1530 \mathrm{~h}$. The 16 -minute testing session consisted of three phases. First, 70-dB white noise was presented for five minutes to acclimatize the mouse to the apparatus; this acoustic stimulus continued throughout the session as background noise. Next, one pulse-alone trial $(120 \mathrm{~dB}, 30$ msec) was presented to orient the mouse. Data from this trial was excluded from subsequent analyses. Then six blocks of trials, containing two pulse-alone trials (P), five prepulse + pulse trials $(\mathrm{PP}+\mathrm{P})$ and one presentation of 70-dB background noise (null), were delivered in pseudo-random order, with an average intertrial interval of 17 seconds (range 9-29 sec). The five $\mathrm{PP}+\mathrm{P}$ trials consisted of a $30-\mathrm{msec}$ prepulse of $75,80,85,90$ or $95 \mathrm{~dB}$ followed by a $70-\mathrm{msec}$ delay and then a startle pulse $(120 \mathrm{~dB}, 30 \mathrm{msec})$.

Null trials were presented to determine the mouse's movement in the testing chamber. The average response to the six null presentations was subtracted from all startle amplitudes resulting from both the $\mathrm{P}$ and $\mathrm{PP}+\mathrm{P}$ trials. The startle amplitudes 
elicited by the $12 \mathrm{P}$ trials were averaged to give the average startle response (ASR). Percentage of prepulse inhibition was calculated with the following formula:

$$
\left[1-\left(\frac{\text { startle amplitude on } \mathrm{PP}+\mathrm{P} \text { trial }}{\mathrm{ASR}}\right)\right] \times 100
$$

\section{Locomotor Testing:}

Locomotor activity was recorded in activity chambers $(17.8 \times 10.4 \times 26.5 \mathrm{~cm})$ equipped with two infrared beams. Locomotor activity counts were recorded when the two parallel infrared beams were interrupted consecutively. Beam interruptions in each box were monitored and stored by a computer.

Each mouse was habituated to the locomotor apparatus for one hour on the day before locomotor testing. Locomotor testing occurred between $0900 \mathrm{~h}$ and $1800 \mathrm{~h}$. On testing days, all mice were injected with $d$-amphetamine solution $(5 \mathrm{mg} / \mathrm{kg}$, s.c.) exactly one hour after their respective treatments (vehicle, clozapine or none) and immediately placed in the locomotor apparatus for a two-hour testing period.

\section{Experimental Schedule:}

After arrival and acclimatization, the mice in both strains were randomly assigned to one of four treatment groups: control, vehicle, $2 \mathrm{mg} / \mathrm{kg}$ and $4 \mathrm{mg} / \mathrm{kg}$ of clozapine. The control group received no injections or manipulation prior to testing. These mice were used to determine the basic strain-specific characteristics in the two behavioral paradigms. Vehicle-treated mice were used as a second control group to observe the effects of handling and injection stresses on behavior. Days one and two consisted of intraperitoneal injections of vehicle or clozapine, accordingly timed to the behavioral 
testing schedule. On day three, each mouse received vehicle, clozapine or no treatment and was placed in the startle apparatus one hour later for prepulse inhibition tests. After testing was completed, the mice were placed in the locomotor apparatus for one hour of habituation. The following day, the mice received vehicle, clozapine or no treatment and were tested for amphetamine-induced locomotor activity for two hours. During the next 14 days, the mice were weighed and given their respective treatments (vehicle, clozapine or none) on a daily basis; this was done to monitor weight gain associated with chronic treatment. Timed vehicle or clozapine injections resumed on days 19 and 20. On days 21 and 22, the mice were once again tested for prepulse inhibition and amphetamineinduced hyperlocomotion.

\section{Experiment 2:}

As previously described, male mice lost weight during the first behavioral testing session. Accordingly, we designed the following experiment to assess differences in clozapine-induced weight gain without the stress of behavioral testing (for detailed rationale, see Hypotheses and Design Rationale).

Animals:

A total of 131 female $\mathrm{C} 57 \mathrm{BL} / 6 \mathrm{~J}$ and $\mathrm{A} / \mathrm{J}$ mice were tested in this experiment (RGS Genome Inc., Montreal, Canada). They were shipped to the Douglas Hospital Research Centre at 7-8 weeks old. They were housed in groups of 10-12 mice per cage in an animal room kept at $20-22{ }^{\circ} \mathrm{C}$, with a relative humidity of $40 \%$ and a 12 -hour light 
cycle (lights on 0800-2000h). Throughout their stay, mice had free access to standard mouse chow and water. The mice were allowed to reach a post-pubertal age of 9-10 weeks to maximize weight gain conditions (for explanation, see Hypotheses and Design Rationale).

\section{Drug Solutions:}

Clozapine (mol. wt. 326.8, Alexis Biochemicals) was dissolved in $5 \mathrm{~N} \mathrm{HCl}$, adjusted to $\mathrm{pH} 7$ with $0.1 \mathrm{~N} \mathrm{NaOH}$, and brought to final volume with $0.9 \%$ sterile saline. Risperidone (mol. wt. 410.5, Sigma Biochemicals) was dissolved in 1.5\% D-tartaric acid (99\%). All injections were administered in a volume of $10 \mathrm{~mL} / \mathrm{kg}$.

\section{Experimental Procedure:}

After the female mice reached the appropriate age of 9-10 weeks, they were separated into seven treatment groups: control, saline, clozapine $(2 \mathrm{mg} / \mathrm{kg} / \mathrm{day}$ and 4 $\mathrm{mg} / \mathrm{kg} /$ day $)$ and risperidone $(0.25 \mathrm{mg} / \mathrm{kg} /$ day, $0.50 \mathrm{mg} / \mathrm{kg} /$ day, $1.00 \mathrm{mg} / \mathrm{kg} /$ day $)$. Again, the control group received no injections or manipulation prior to testing. These mice were used to determine the basic strain-specific characteristics in the two behavioral paradigms. Saline-treated mice were used as a second control group to observe the effects of handling and injection stresses on behavior. Treated mice were injected subcutaneously twice daily (approximately at $0930 \mathrm{~h}$ and $1830 \mathrm{~h}$ ) and monitored for 21 days. Weight recordings were taken every 3-4 days to minimize constant stress due to overmanipulation. 


\section{Data Analysis:}

For experiment 1 , mice were excluded from data analysis if they did not complete the 22-day testing period due to equipment failure, experimental error, or death. For prepulse inhibition analyses, mice were also excluded if their mean startle values were at least 1.5 standard deviations below the mean for their strain. Sixteen mice were excluded from prepulse inhibition analyses, resulting in a total of 106 mice included in these analyses; the final numbers of mice in each treatment group in the $\mathrm{A} / \mathrm{J}$ and $\mathrm{C} 57 \mathrm{BL} / 6 \mathrm{~J}$ strains, respectively, are as follows: control $=14$ and 13 , vehicle $=14$ and $13,2 \mathrm{mg} / \mathrm{kg}$ clozapine $=14$ and $12,4 \mathrm{mg} / \mathrm{kg}$ clozapine $=14$ and $12 . \quad$ Eighteen mice were excluded from locomotor analyses, resulting in a total of 104 mice used for these analyses; the final numbers of mice in each treatment group in the $\mathrm{A} / \mathrm{J}$ and $\mathrm{C} 57 \mathrm{BL} / 6 \mathrm{~J}$ strains, respectively, are as follows: control $=13$ and 13 , vehicle $=13$ and $13,2 \mathrm{mg} / \mathrm{kg}$ clozapine $=13$ and 12 , $4 \mathrm{mg} / \mathrm{kg}$ clozapine $=14$ and 13 . For weight gain analyses, only three mice were excluded due to either sickness or death; the final numbers of mice in each treatment group in each strain ranged from 13-16. In experiment 2 , all female mice were included in weight analyses; final numbers of mice ranged from 8-10 mice in each treatment group in each strain.

Since behavioral testing occurred over a large span of time (October 2000 to April 2001), we assessed the reliability of the behavioral measures both across time and within each of the eight treatment groups (four treatments $\mathrm{x}$ two strains). Using mid-January 2001 as a cut-off point, mice in each treatment group were divided into early- and latetested sets for time comparisons. For between-subject comparisons, mice were sequentially numbered within each treatment group and then separated into odd- and 
even-numbered sets, irrespective of testing time. To further test reliability in prepulse inhibition recordings across the two testing chambers, the mice were categorized according to their startle chamber to determine any chamber effects; again, this was done within each treatment group. Independent t-tests were performed on the time-, numberand chamber-divided sets to assess reliability. Among all comparisons, there were only two significant differences found in the number-divided comparisons at the .05 level. However, when the alpha level was corrected for the number of comparisons performed on the data ( 8 treatment groups $\mathrm{x} 16$ outcome variables $\mathrm{x} 3$ comparisons), these differences were no longer significant. Thus no time, number, or chamber effects were discovered.

Three-way analyses of variance (ANOVA) for repeated measures were performed on the prepulse inhibition, locomotor, and weight gain data to assess effects of strain, treatment, and time factors. Simple effects tests were used to analyze significant interactions, and Tukey's honest significant difference test was used for post-hoc analyses. For our purposes, the most informative ANOVA result is the two-way interaction between strain and treatment. While a three-way significant interaction is highly informative, post-hoc tests may reveal that the interaction between strain $\mathrm{x}$ treatment only occurs at a particular point in time, rather than a global interaction across time. A significant strain $\mathrm{x}$ treatment interaction would indicate a true strain difference in responses to clozapine treatment throughout the entire testing period. 


\section{RESULTS}

\section{Experiment 1: Male mice, 6-8 weeks old}

\section{Prepulse Inhibition: 3 days}

A three-way repeated measures ANOVA (strain $\mathrm{x}$ treatment $\mathrm{x}$ trial) on the 12 startle trials revealed significant main effects of strain, treatment and trial [all ps $<.01$, and a significant strain $x$ trial interaction $[F(11,1078)=1.99 ; p<.05]$. Since this interaction suggests basic strain differences in startle response across trials, post-hoc tests were not performed. The significant strain effect revealed that all C57BL/6J mice had higher startle responses than $\mathrm{A} / \mathrm{J}$ mice $[\mathrm{F}(1,98)=5.37 ; \mathrm{p}<.01]$. Post-hoc analysis of the treatment factor determined that mice treated with $4 \mathrm{mg} / \mathrm{kg}$ of clozapine $(\mathrm{n}=26)$ had lower startle responses than mice receiving either vehicle $(\mathrm{n}=27)$ or $2 \mathrm{mg} / \mathrm{kg}$ of clozapine $(n=26)$, regardless of strain [table 1 ; all ps $<.01$ ]. Other experiments have also reported clozapine-induced reduction in startle responses, but since prepulse inhibition is calculated as proportion of the startle response, the resulting value of prepulse inhibition is not affected.

Prepulse + pulse trials $(\mathrm{PP}+\mathrm{P})$ were presented six times throughout the testing session. Each presentation consisted of a prepulse of $75,80,85,90$, or $95 \mathrm{~dB}$ given 70 milliseconds before the startle pulse. Startle responses recorded from these trials were converted into percentages of prepulse inhibition (see formula in Materials and Methods). Three-way repeated measures ANOVAs (strain $\mathrm{x}$ treatment $\mathrm{x}$ presentation) were performed on the data resulting from the six presentations of each of the five $\mathrm{PP}+\mathrm{P}$ trial types. Analyses uncovered significant findings only for $75-$ or $80-\mathrm{dB}$ prepulse intensities. For the $75-\mathrm{dB} P \mathrm{PP}+\mathrm{P}$ trials, the three-way ANOVA revealed only significant main effects 
of treatment $[\mathrm{F}(3,98)=2.73 ; \mathrm{p}<.0479]$ and presentation $[\mathrm{F}(5,490)=4.27 ; \mathrm{p}<.0008]$, but no significant interactions. Post-hoc analysis of the treatment factor determined that mice treated with $4 \mathrm{mg} / \mathrm{kg}$ of clozapine $(\mathrm{n}=26)$ had increased prepulse inhibition when compared to vehicle-treated mice $(n=27)$, irrespective of mouse strain [figure $1 ; \mathrm{p}<$ .05]. Post-hoc tests on the presentation factor showed that the first prepulse trial elicited lower prepulse inhibition percentages than the second and fifth trials [all ps $<.01$ ].

For the $80-\mathrm{dB} P P+\mathrm{P}$ trials, the three-way ANOVA resulted in only a significant treatment effect $[\mathrm{F}(3,490)=3.67 ; \mathrm{p}<.0147]$. Post-hoc analysis revealed that mice treated with $4 \mathrm{mg} / \mathrm{kg}$ of clozapine $(\mathrm{n}=26)$ had higher prepulse inhibition than mice treated with either vehicle $(n=27)$ or $2 \mathrm{mg} / \mathrm{kg}$ of clozapine $(n=26)$, regardless of strain [figure 2; all ps $<.05]$.

Since no significant strain $\mathrm{x}$ treatment interaction was found in any of the five prepulse trial types $[\mathrm{Fs}(3,98) \geq 0.29 ;$ ps $>.1]$, we may conclude that short-term $(3$-day) clozapine treatment did not affect prepulse inhibition differently in the two inbred mouse strains.

\section{Prepulse Inhibition: 21 days}

A three-way ANOVA on the 12 startle trials resulted in significant main effects of strain and trial $[$ all ps $<.0001]$ and a significant strain $\mathrm{x}$ interaction $[\mathrm{F}(11,1078)=1.96 ; \mathrm{p}$ $<.0288$ ]. Again, since this interaction merely tells us that the startle responses differed between both strains across trials, post-hoc analyses were not performed. The significant strain effect again revealed that $\mathrm{C} 57 \mathrm{BL} / 6 \mathrm{~J}$ mice had higher startle responses than $\mathrm{A} / \mathrm{J}$ 
mice $[F(1,98)=43.51 ; p<.0001]$. Clozapine did not affect startle responses after 21 days of treatment.

A three-way repeated measures ANOVA on the data for prepulse inhibition revealed significant findings only in $85-\mathrm{dB} P P+P$ trials. While there was a significant three-way interaction $[F(15,490)=1.86 ; \mathrm{p}<.0250]$, simple effect analyses and subsequent post-hoc analyses revealed that $A / J$ mice treated with vehicle $(n=14)$ exhibited wide variations in prepulse inhibition values across most of the six presentations of the $85-\mathrm{dB} \mathrm{PP}+\mathrm{P}$ trials [all ps $<.05]$. Moreover, at one 85-dB presentation, vehicle-treated $\mathrm{A} / \mathrm{J}$ mice had significantly lower prepulse inhibition than all other treatment groups in the $\mathrm{A} / \mathrm{J}$ strain and vehicle-treated C57BL/6J mice $(n=13)$ [all ps $<.05]$. There was no significant interaction between strain and treatment nor main effects of treatment or strain.

These results suggest that long-term (21-day) clozapine treatment did not globally affect prepulse inhibition. The absence of a significant strain $\mathrm{x}$ treatment interaction in any of the $5 \mathrm{PP}+\mathrm{P}$ trial types $[\mathrm{Fs}(3,98) \geq 0.16$; ps $>.2]$ suggests that 21 -day clozapine treatment did not affect prepulse inhibition differently in the two inbred mouse strains.

\section{AMPH-induced Hyperlocomotion: 4 days}

The locomotor activity counts recorded throughout the 120 -minute testing period were analyzed in 10-minute bins to assess activity trends over time. A three-way repeated measures ANOVA on the entire testing session revealed a significant three-way interaction between strain, treatment, and time $[F(33,1056)=1.52 ; p<.0305]$. Simple effects analyses determined that locomotor activity was different between treatment 
groups in the $\mathrm{A} / \mathrm{J}$ strain only at 10 and 20 minutes $[\mathrm{Fs}(3,1056) \geq 2.96$; ps $<.05]$. Simple effects analyses also revealed treatment differences among the C57BL/6J mice in the locomotor activity recorded from $20-120$ minutes [Fs $(3,1152) \geq 7.84 ; \mathrm{ps}<.0001]$. This indicates that for the majority of the testing session, treatment effects were only seen in the $\mathrm{C} 57 \mathrm{BL} / 6 \mathrm{~J}$ strain. In figure 3 , we can see that these results are due to very different responses to amphetamine in the two inbred mouse strains. In the A/J strain, the effects of amphetamine are transient; amphetamine increased locomotion up to 20 minutes and then lost its effect shortly thereafter. Locomotor activity counts drop sharply to almost baseline levels. In the $\mathrm{C} 57 \mathrm{BL} / 6 \mathrm{~J}$ strain, the amphetamine effects peaked at 40 minutes and then slowly declined. At the end of the 120-minute testing session, locomotor activity had not yet dropped to baseline levels.

To correct for these contrasting responses to amphetamine, we analyzed the peaks of locomotor activity to determine if clozapine treatment successfully reduced amphetamine-induced hyperlocomotion. In the $\mathrm{A} / \mathrm{J}$ strain, the activity peak was found at 20 minutes, while it was found at 40 minutes for the C57BL/6J strain. A two-way ANOVA (strain $x$ treatment) on peak activity counts revealed significant main effects of both strain $[F(1,96)=23.74 ; p<.00001]$ and treatment $[F(3,96)=10.93 ; p<.00001]$, but there was no significant two-way interaction between these factors. Subsequently, we performed two-way ANOVAs again, but this time we tested each clozapine dose separately against the control and vehicle groups. A two-way ANOVA that only included the $2-\mathrm{mg} / \mathrm{kg}$ clozapine dose resulted in only a significant main effect of strain [F $(1,71)=26.41 ; \mathrm{p}<.000002] ;$ no significant treatment effect or two-way interaction was found. The two-way ANOVA with the 4-mg/kg clozapine dose revealed no strain $\mathrm{x}$ 
treatment interaction, but the significant main effects of strain $[\mathrm{F}(1,73)=22.92 ; \mathrm{p}<$ $.00001]$ and treatment were present $[\mathrm{F}(2,73)=14.29 ; \mathrm{p}<.00001]$. The $\mathrm{C} 57 \mathrm{BL} / 6 \mathrm{~J}$ strain had higher amphetamine-induced locomotor activity counts overall. Post-hoc analyses determined that $4 \mathrm{mg} / \mathrm{kg}$ of clozapine significantly reduced locomotor activity counts in mice $(n=27)$ when compared with the control $(n=26)$ and vehicle-treated $(n=26)$ mice [figure 4; all ps $<.01$ ]. These results suggest that only the higher clozapine dose contributes to the significant treatment effect. Importantly, the treatment effect and the absence of a strain $x$ treatment interaction indicate that $4 \mathrm{mg} / \mathrm{kg}$ of clozapine reduced amphetamine-induced hyperlocomotion equally in both mouse strains.

Amphetamine-induced Hyperlocomotion: 22 days

A three-way ANOVA for repeated measures revealed a significant three-way interaction $[F(33,1056)=1.90 ; \mathrm{p}<.0018]$. Simple effects tests and post-hoc analyses found that treatment effects occurred only within the first 40 minutes of the testing period [all ps $<.05]$. Again, different activity profiles were seen in all treatment groups in both strains. Within the $\mathrm{A} / \mathrm{J}$ strain, the vehicle-treated group $(\mathrm{n}=13)$ and the group receiving $2 \mathrm{mg} / \mathrm{kg}$ of clozapine $(\mathrm{n}=13)$ had peak activity counts at 10 minutes, while the activity of the controls $(n=13)$ and mice treated with $4 \mathrm{mg} / \mathrm{kg}$ of clozapine $(n=14)$ peaked at 20 minutes (figure 5). Within the $\mathrm{C} 57 \mathrm{BL} / 6 \mathrm{~J}$ strain, the peak activity of mice treated with the higher clozapine dose $(n=13)$ was at 30 minutes, while the peak activity was at 20 minutes for the other three treatment groups $(\mathrm{ns}=12-13)$. Given the varying amphetamine-response profiles among all treatment groups in each strain, we performed two-way ANOVAs on the areas under the locomotor activity curves for each clozapine 
dose separately. Both two-way ANOVAs on the areas under the curve resulted in only a strain effect $[\mathrm{F}(1,96)=72.29 ; \mathrm{p}<.000001]$, indicating that $\mathrm{C} 57 \mathrm{BL} / 6 \mathrm{~J}$ mice had higher locomotor activity than $\mathrm{A} / \mathrm{J}$ mice in response to amphetamine administration. No significant treatment effects or strain $\mathrm{x}$ treatment interactions were found at either dose. These results indicate that clozapine did not affect amphetamine-induced hyperlocomotion after long-term (22-day) treatment.

\section{Weight Gain:}

Figure 6 shows the recorded weights in the $\mathrm{A} / \mathrm{J}$ and $\mathrm{C} 57 \mathrm{BL} / 6 \mathrm{~J}$ mice across all treatment groups throughout most of the 22-day testing period. A one-way ANOVA performed on the weight change from day 0 (day before experiment began) to day 5 (day after first behavioral testing session) revealed that both mouse strains lost weight; the $\mathrm{A} / \mathrm{J}$ strain lost more weight than the C57BL/6J strain, irrespective of treatment $[\mathrm{F}(1,111)=$ $35.49 ; \mathrm{p}<.000001]$

Weights were recorded for 14 consecutive days between behavioral testing sessions (days 5-18). Statistical analyses were performed on the daily weight changes relative to weights recorded on day 5. A three-way ANOVA for repeated measures resulted in significant main effects of strain $[F(1,111)=5.141 ; p<.0253]$ and day $[F$ $(12,1332)=48.002 ; p<.000001]$, but no significant treatment effect or strain $x$ treatment interaction was found [all ps $>.06]$. The A/J strain $(\mathrm{n}=61)$ gained more weight than the C57BL/6J strain $(\mathrm{n}=58)$, and post-hoc analysis on the day factor determined that there was significant weight gain on an almost-daily basis [all ps $<.045$ ]. However, clozapine had no significant effect on weight gain in either strain. 
These results suggest that the first session of behavioral testing was stressful for the mice and may have caused them to lose weight. The mice regained the weight during the ensuing 14-day period. Interestingly, the $\mathrm{A} / \mathrm{J}$ strain may be more susceptible to stress caused by manipulation. These mice lost more weight than the $\mathrm{C} 57 \mathrm{BL} / 6 \mathrm{~J}$ mice after behavioral testing, and with less stressful manipulation during the 14-day period, they gained more weight than the C57BL/6J mice.

\section{Experiment 2: Weight gain in female mice, 9-10 weeks old}

Treated female $\mathrm{A} / \mathrm{J}$ and $\mathrm{C} 57 \mathrm{BL} / 6 \mathrm{~J}$ mice were given two subcutaneous injections per day of saline, clozapine ( 2 or $4 \mathrm{mg} / \mathrm{kg}$ ) or risperidone $(0.25,0.5$ or $1.0 \mathrm{mg} / \mathrm{kg}$ ) for 21 days. Three-way ANOVA for repeated measures was performed on the weight changes relative to weights on day 1 , recorded every 3-4 days (figures 7-8). A significant strain $\mathrm{x}$ treatment $x$ day interaction was found $[F(30,585)=1.59 ; p<.0251]$. Simple effects tests and post-hoc analyses determined that the weight change for the controls were significantly greater than all the other treatment groups in the A/J strain [all ps $<.05$ ]. All A/J mice receiving treatment of any kind, including saline, lost significant amounts of weight from days $7-21$, while the control mice $(n=10)$ gained weight (figure 7$)$. Simple effects tests also determined that C57BL/6J mice that received either $0.5 \mathrm{mg} / \mathrm{kg} / \mathrm{day}(\mathrm{n}=$ 10) or $1.0 \mathrm{mg} / \mathrm{kg} /$ day $(\mathrm{n}=9)$ of risperidone had different weight changes when compared to $\mathrm{A} / \mathrm{J}$ mice receiving the same doses ( $\mathrm{ns}=10$ and 8 , respectively); $\mathrm{C} 57 \mathrm{BL} / 6 \mathrm{~J}$ mice treated with either of the two higher risperidone doses gained a little weight, while the $\mathrm{A} / \mathrm{J}$ mice receiving the same doses lost weight $[\mathrm{Fs}(1,702) \geq 4.08$; all ps $<.0452]$. 
Importantly, compared to saline administration, clozapine had no significant effect on weight change in either strain.

Since neither males nor females in either strain gained (or lost) significant amounts of weight under clozapine treatment, no correlations can be performed between weight gain and behavioral responses to clozapine treatment. 


\section{DISCUSSION:}

Several clinical observations and studies have reported that responses to clozapine treatment vary considerably among schizophrenic patients. While clinical studies have made progress in determining potential genetic factors underlying these response variations, heterogeneous methodological factors, such as treatment length and clinical measures of improvement, have resulted in inconsistent findings. Consequently, to perform a more controlled study of treatment response variations, these experiments were designed to determine if behavioral and metabolic responses to either short- or long-term clozapine treatment differed between two strains of mice. The results suggest that only short-term clozapine treatment in mice both improved prepulse inhibition and reduced amphetamine-induced hyperlocomotion, two proposed indices of therapeutic response. While the $\mathrm{A} / \mathrm{J}$ and $\mathrm{C} 57 \mathrm{BL} / 6 \mathrm{~J}$ control mice exhibited basic strain differences in both prepulse inhibition and amphetamine-induced hyperlocomotion, these two behaviors were affected by clozapine treatment equally in both mouse strains. While this may suggest the lack of genetic differences underlying clozapine responses in these inbred mouse strains, one can not exclude the possibility that the random fixation of various genes during the inbreeding process might lead to phenotypically similar levels of these traits in the two strains. This may result from divergent alleles at a number of genetic loci. To test this latter hypothesis, a more thorough examination of these clozapineinduced behaviors with the recombinant congenic strains derived from these two parental lines is needed. 
The absence of behavioral responses to long-term clozapine treatment complements the findings of both Andersen and Pouzet (2001) and Martinez et al. (2000). Both of these studies observed robust improvement of dopamine-agonist-induced behaviors after short-term treatment with various antipsychotic compounds. Furthermore, the Andersen/Pouzet study (2001) determined that the reversal of amphetamine-induced behaviors after three days of antipsychotic treatment was stronger than the reversal resulting from just one acute administration of antipsychotic medication. However, after long-term treatment (21 days or more) with antipsychotics, the ability to reverse the effects of dopamine agonists either decreases or disappears altogether. In the rodent model, treatment with antipsychotics may induce changes that may render targeted neurotransmitter systems less responsive to antipsychotics over time. One study reported that chronic antipsychotic treatment (21 days) in rats resulted in increased sensitivity to subsequent dopamine challenges (Halperin et al., 1989). Speculatively, chronic treatment with antipsychotics may increase the synaptic availability of dopamine receptors. As a result, the effective dose that reversed dopamine-induced behaviors after acute or subchronic treatment may not be enough to block the increased number of dopamine receptors. This, in turn, leaves more receptors available to bind dopamine, rendering the rodent more sensitive to its effects. Future experiments may require the titration of doses during the course of antipsychotic treatment to effectively reverse dopamine-induced behaviors over time.

Although clozapine treatment altered behavioral measures in this experiment, metabolic changes were not seen following chronic clozapine treatment. Following two weeks of weight observations, male mice in both strains gained weight, but clozapine- 
treated mice did not gain more weight than either control or vehicle-treated mice. In addition, female mice either lost or stabilized their body weight when given injections of either saline or clozapine over a 21-day period; body weight changes under clozapine treatment did not significantly differ between strains. These results suggest that neither the $\mathrm{C} 57 \mathrm{BL} / 6 \mathrm{~J}$ nor the $\mathrm{A} / \mathrm{J}$ inbred mouse strain is a good model of clozapine-induced weight gain under our experimental conditions.

Overall, the lack of strain differences in behavioral and metabolic responses to short-term clozapine treatment suggests that the C57BL/6J and $\mathrm{A} / \mathrm{J}$ inbred mouse strains respond to clozapine in a similar manner. As aforementioned, the recombinant congenic strains derived from these parental lines may uncover differences in responses to clozapine among the various strains. Should no differential responses to clozapine arise, the investigation of genetic differences underlying clozapine responses may still require the use of more appropriate parental mouse strains and their derived recombinant congenic strains. Some studies have already looked at the effects of clozapine treatment on prepulse inhibition in different inbred mouse strains. McCaughran and colleagues reported that clozapine treatment increased prepulse inhibition in both the $\mathrm{C} 57 \mathrm{BL} / 6 \mathrm{~J}$ and DBA/2J inbred mouse strains equally (McCaughran Jr et al., 1997). Similarly, Olivier and his team observed that clozapine treatment improved prepulse inhibition in the C57BL/6J, DBA/2J, and 129S6/SvEvTac inbred mouse strains, with no differential response among the strains (Olivier et al., 2001). Another experiment by Ouagazzal and colleagues (2001) tested the effects of clozapine treatment in the C57BL/6J, 129S6/SvEv, MORO, and BALB/cByJ inbred mouse strains. With a high prepulse intensity, clozapine treatment increased prepulse inhibition in all strains except the $129 / \mathrm{SvEv}$ strain. This 
strain already had a high prepulse inhibition level, so clozapine's inability to increase the level of prepulse inhibition may be due to a ceiling effect (Ouagazzal et al., 2001). Since the C57BL/6J mouse strain has been repeatedly shown to respond well to clozapine treatment, this may be a good strain to use in future experiments. However, the other strain still must be found. Ideally, the other mouse strain should have a similar prepulse inhibition level as the C57BL/6J strain to avoid a ceiling effect as seen in the Ouagazzal study (2001). Comparison studies of prepulse inhibition levels among several inbred mouse strains suggest that the DBA/2J strain exhibits prepulse inhibition levels similar to the C57BL/6J strain (Bullock et al., 1997; Paylor and Crawley, 1997). However, the McCaughran et al. (1997) and Olivier et al. (2001) studies have already reported no differential responses to clozapine treatment between these strains in the prepulse inhibition paradigm. More appropriate strains with similar prepulse inhibition levels as the $\mathrm{C} 57 \mathrm{BL} / 6 \mathrm{~J}$ strain may include the $\mathrm{C} 57 \mathrm{BL} / 10 \mathrm{~J}$ and $\mathrm{C} 3 \mathrm{H}$ inbred mouse strains [see Bullock et al. (1997) and Paylor \& Crawley (1997)].

Once the appropriate mouse strains are found, the experimental protocol must be adjusted to maximize the detection of strain differences in responses to clozapine treatment. Notably, while these mouse strains may have similar prepulse inhibition levels, they may respond to amphetamine differently and present significantly different locomotor activity. In this study, $\mathrm{A} / \mathrm{J}$ and $\mathrm{C} 57 \mathrm{BL} / 6 \mathrm{~J}$ mice had significantly different locomotor responses to amphetamine, regardless of treatment group (figures 3 and 5). This may suggest potential differences in either absorption or elimination of amphetamine between the two strains. Once clozapine is administered to reduce amphetamine-induced hyperlocomotion, different amphetamine responses will 
undoubtedly complicate observations of clozapine's effects in both mouse strains. Therefore, prepulse inhibition may be a more straightforward and practical paradigm than amphetamine-induced hyperlocomotion for investigating strain differences in therapeutic response to clozapine.

Our prepulse inhibition results suggest some useful changes to prepulse inhibition protocols for future experiments as well. Clozapine treatment improved prepulse inhibition at only the two lowest prepulse intensities. These findings support some observations of clozapine-induced potentiation of prepulse inhibition at low prepulse intensities, ranging from 1-5 dB above background noise levels (Geyer et al., 2001; Swerdlow and Geyer, 1993). Furthermore, the Ouagazzal et al. (2001) study revealed that a prepulse intensity of $4 \mathrm{~dB}$ above background showed strain differences in clozapine response - only the C57BL/6J strain exhibited increased prepulse inhibition in response to clozapine treatment when compared to other mouse strains. Subsequent studies should therefore use low prepulse intensities to maximize clozapine's ability to improve prepulse inhibition and detect possible strain variations in clozapine-induced potentiation of prepulse inhibition.

Long-term (21 - or 22-day) treatment with clozapine had no effect on behaviors related to therapeutic response (prepulse inhibition and amphetamine-induced locomotion) or on weight gain in our experiments. Accordingly, the hypothesized link between weight gain and modeled therapeutic response to antipsychotics could not be studied in our experiments. Subsequent experiments may be able to investigate this link following titration of clozapine doses over time and procedural modifications to maximize weight gain. A recent study by Kaur and Kulkarni reported significant weight 
gain in female albino mice treated with clozapine for 21 days (Kaur and Kulkarni, 2002). Specifically, these investigators observed weight gain with only one injection per day and a diet consisting of standard mouse chow with $10 \%$ sucrose added to enhance food palatability. Future weight gain experiments can adopt their thorough procedure to maximize clozapine-induced weight gain in mice [for details, see Kaur \& Kulkarni (2002)].

Hence, possible genetic differences underlying clozapine responses can still be studied in mice after carefully selecting the mouse strains and experimental parameters. Once response differences are found between particular mouse strains, potential genetic factors governing these differential clozapine responses can be further investigated using quantitative trait loci analyses. 


\section{TABLE AND FIGURES}

A/J

\section{C57BL/6J}

Control

Vehicle

Clozapine $2 \mathrm{mg} / \mathrm{kg}$

Clozapine $4 \mathrm{mg} / \mathrm{kg}$
$157.25 \pm 25.57$

$151.73 \pm 23.69$

$148.65 \pm 23.88$

$61.10 \pm 14.25^{*}$
$227.91 \pm 30.43$

$247.01 \pm 34.75$

$246.12 \pm 49.56$

$132.99 \pm 36.47^{*}$

Table 1. Mean startle response \pm SEM (measured in arbitrary units) after short-term (3day) clozapine treatment in $\mathrm{A} / \mathrm{J}$ and $\mathrm{C} 57 \mathrm{BL} / 6 \mathrm{~J}$ inbred mouse strains. $\mathrm{C} 57 \mathrm{BL} / 6 \mathrm{~J}$ mice had higher startle responses than $\mathrm{A} / \mathrm{J}$ mice, regardless of treatment $[\mathrm{p}<.01]$. Both $\mathrm{A} / \mathrm{J}$ and $\mathrm{C} 57 \mathrm{BL} / 6 \mathrm{~J}$ mice treated with $4 \mathrm{mg} / \mathrm{kg}$ of clozapine had lower startle responses than mice receiving either vehicle or $2 \mathrm{mg} / \mathrm{kg}$ of clozapine [denoted by an asterisk $\left(^{*}\right)$, all $\mathrm{ps}<$ $.01]$ 


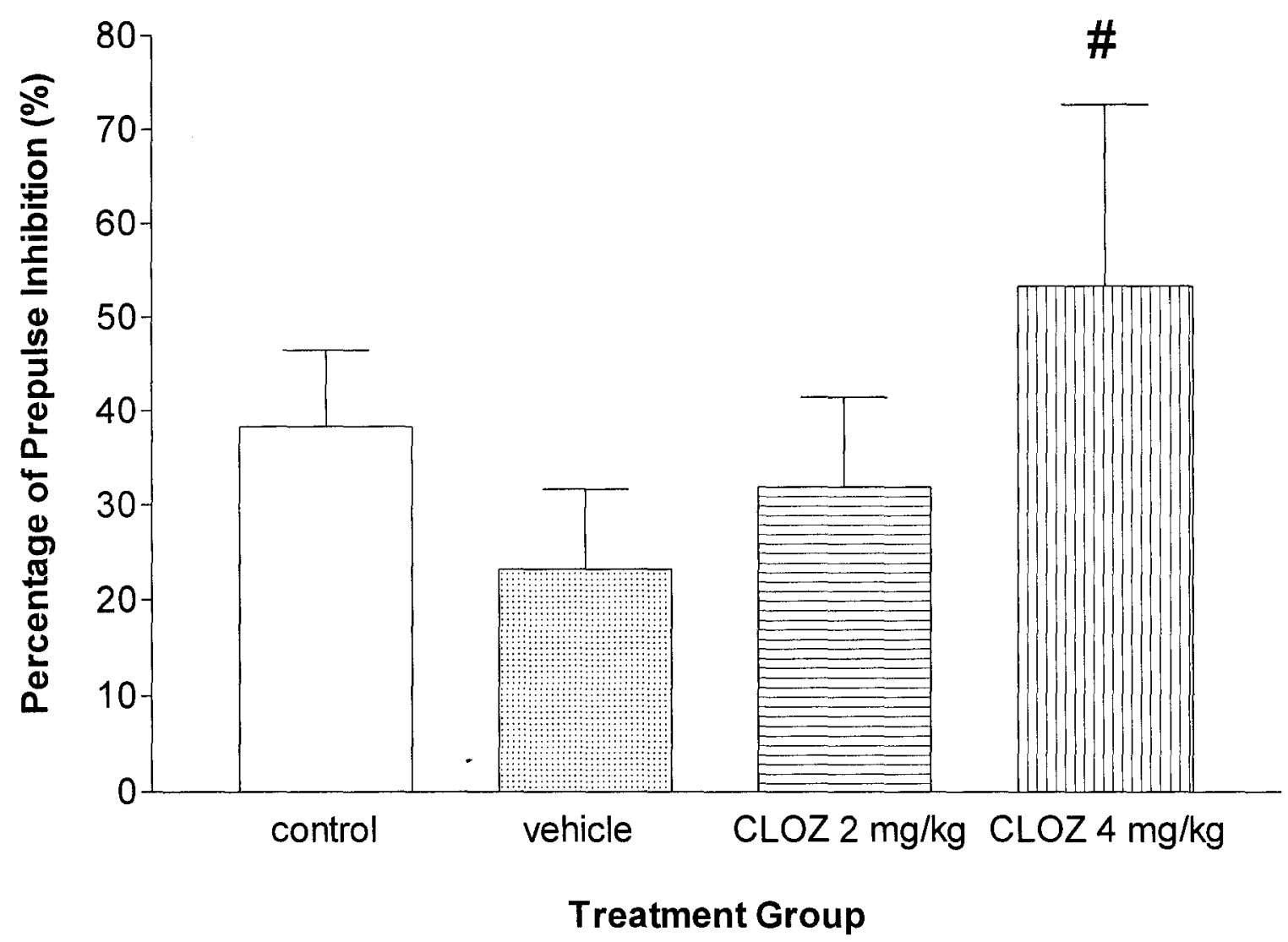

Figure 1. Short-term (3-day) clozapine treatment effects on prepulse inhibition with a prepulse of $75 \mathrm{~dB}$. Bars represent mean + SEM for percentage of prepulse inhibition. Since there was no significant strain effect or strain $\mathrm{x}$ treatment interaction, data have been collapsed across the two strains $(\mathrm{A} / \mathrm{J}$ and $\mathrm{C} 57 \mathrm{BL} / 6 \mathrm{~J})$. Mice in both strains treated with $4 \mathrm{mg} / \mathrm{kg}$ of clozapine had higher prepulse inhibition than mice receiving vehicle [denoted by a number sign $(\#), \mathrm{p}<.05]$. 


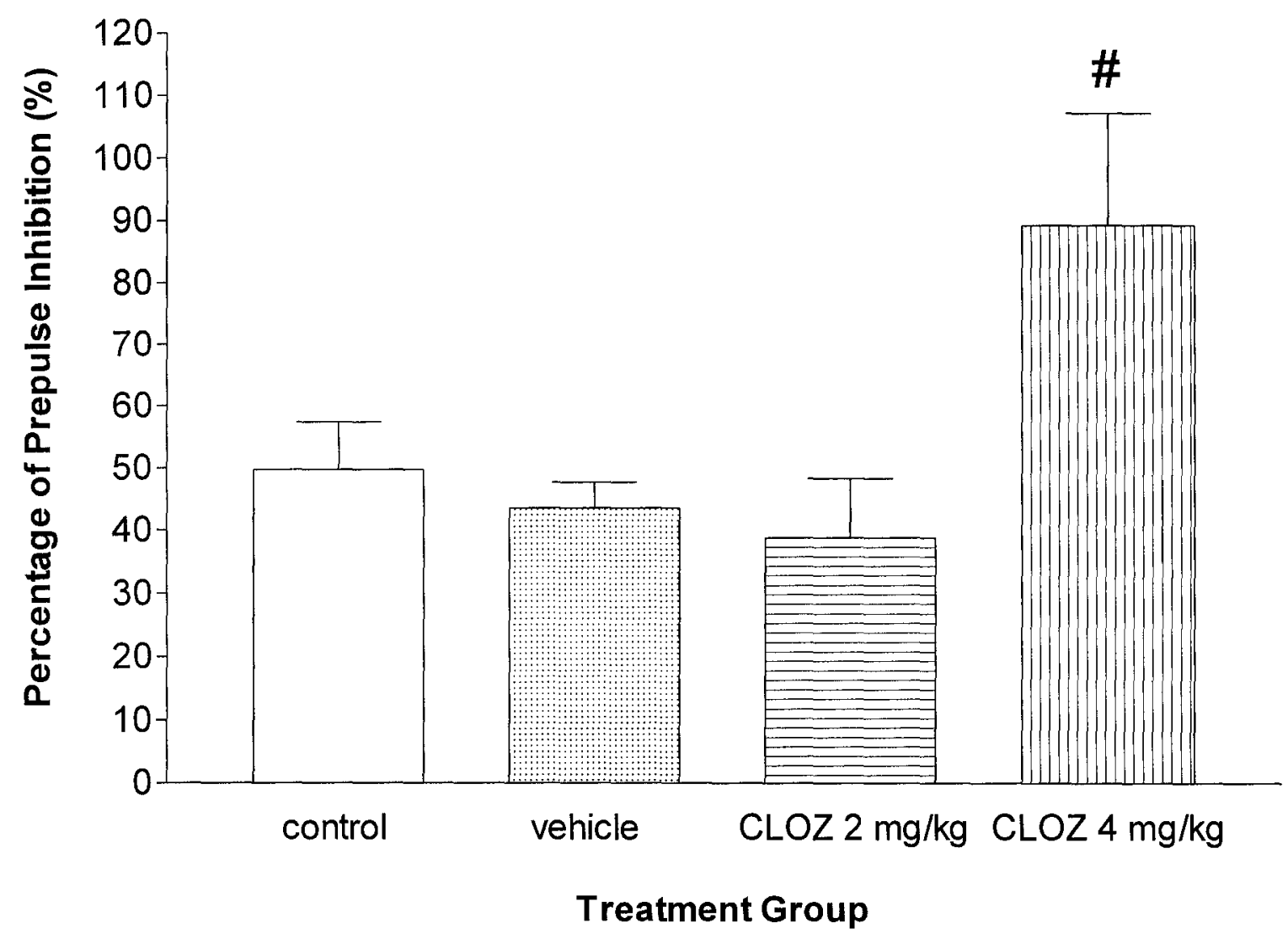

Figure 2. Short-term (3-day) clozapine treatment effects on prepulse inhibition with a prepulse of $80 \mathrm{~dB}$. Bars represent mean + SEM for percentage of prepulse inhibition. Since there was no significant strain effect or strain $\mathrm{x}$ treatment interaction, data have been collapsed across the two strains (A/J and C57BL/6J). Mice in both strains treated with $4 \mathrm{mg} / \mathrm{kg}$ of clozapine had higher prepulse inhibition than mice receiving vehicle or 2 $\mathrm{mg} / \mathrm{kg}$ of clozapine [denoted by a number sign $(\#)$, ps $<.05$ ]. 


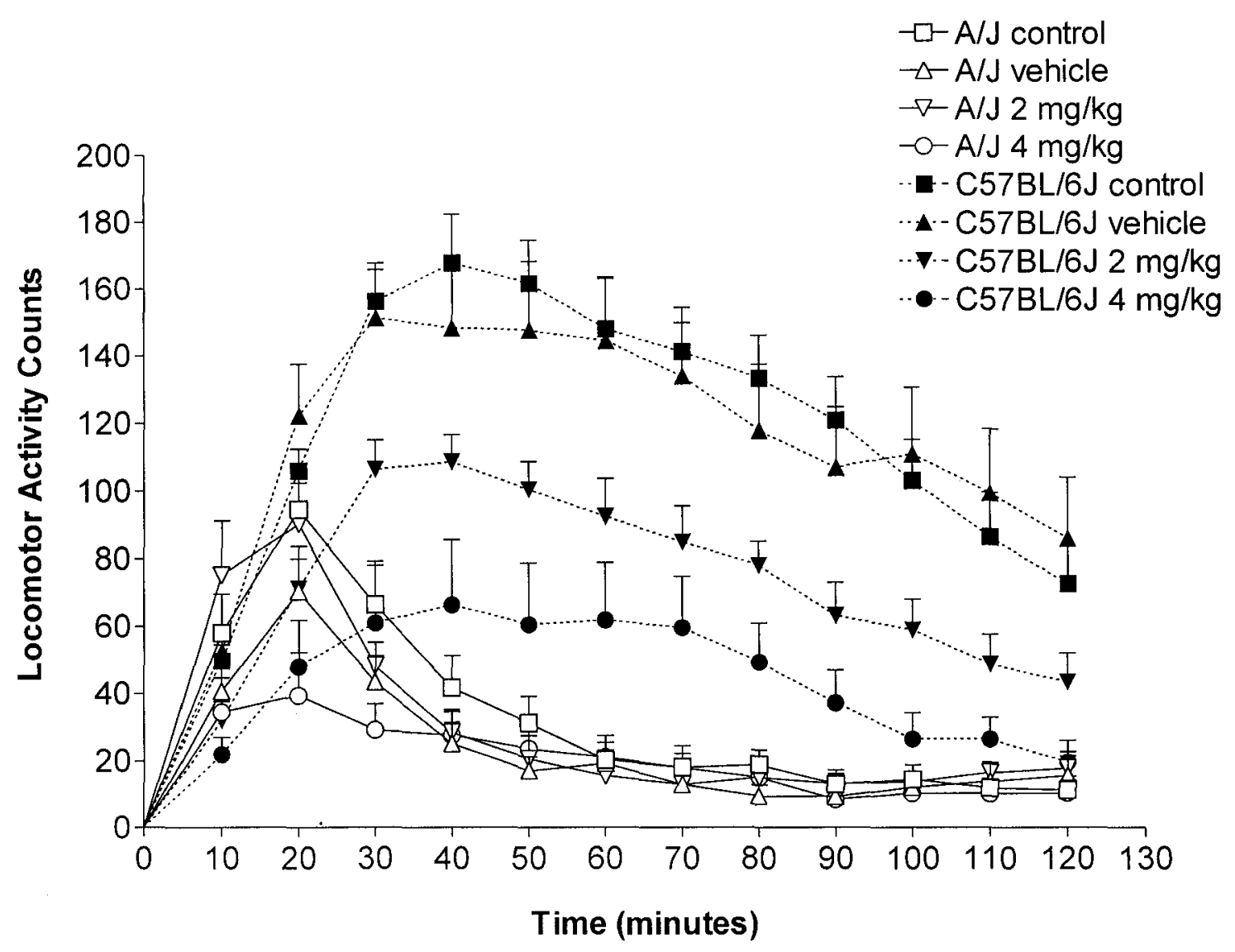

Figure 3. Patterns of amphetamine-induced hyperlocomotion after short-term (4-day) clozapine treatment. Data points represent mean + SEM for locomotor activity counts. The two inbred mouse strains have contrasting amphetamine response profiles $[p<$ .0305]. The A/J strain's activity counts peak at 20 minutes and then sharply decline, while the $\mathrm{C} 57 \mathrm{BL} / 6 \mathrm{~J}$ strain's activity counts peak at 40 minutes and decline at a much slower rate. $\mathrm{C} 57 \mathrm{BL} / 6 \mathrm{~J}$ mice had higher locomotor activity counts at the peaks than $\mathrm{A} / \mathrm{J}$ mice $[p<.00001]$. 


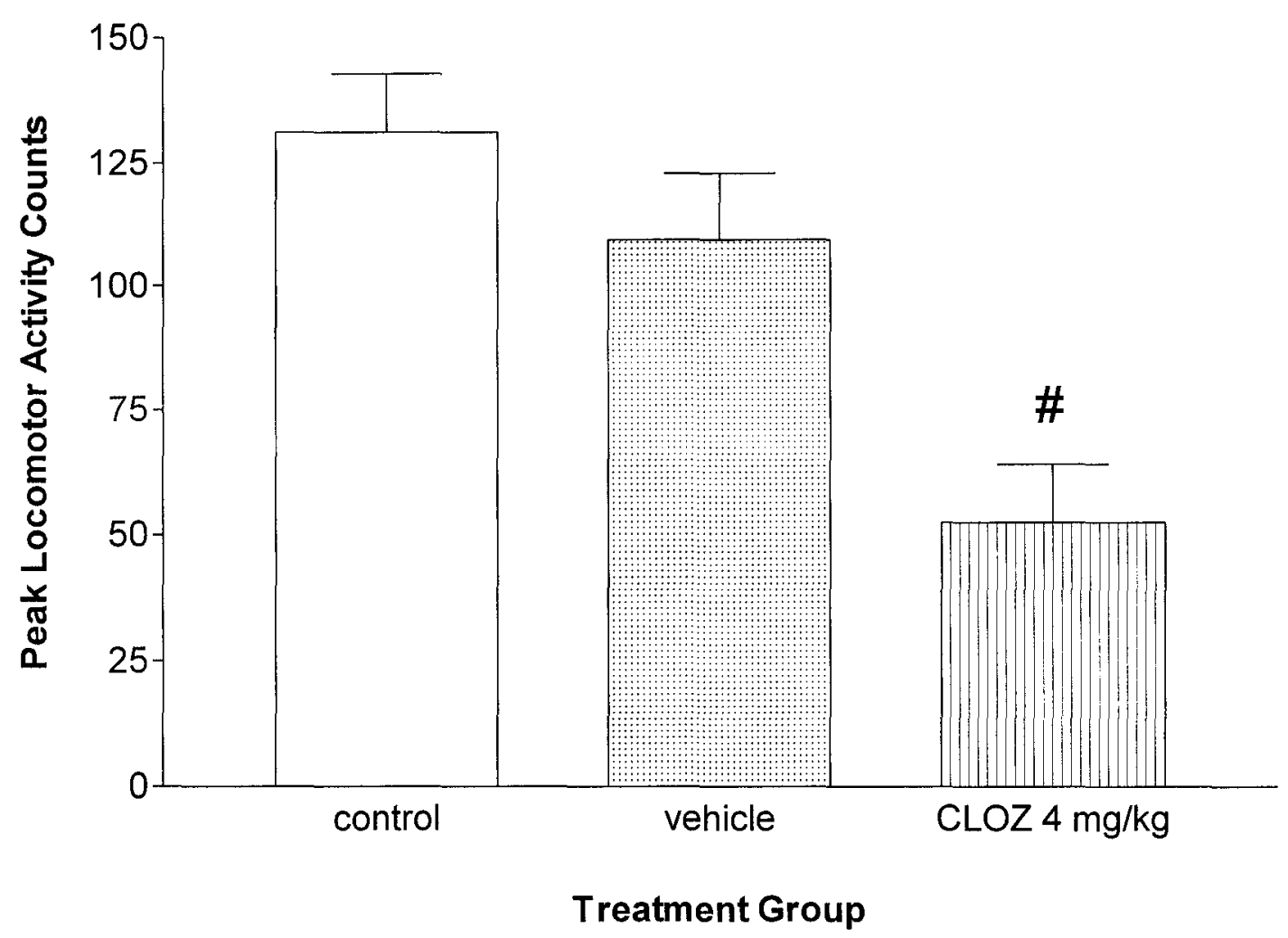

Figure 4. Short-term (4-day) clozapine treatment effects on peaks of amphetamineinduced locomotor activity. Bars represent the mean + SEM for the highest locomotor activity counts in the testing session for each treatment group. Data have been collapsed across the two strains (A/J and C57BL/6J). Mice that received $4 \mathrm{mg} / \mathrm{kg}$ of clozapine had lower locomotor activity counts than control mice or vehicle-treated mice, irrespective of strain [denoted by a number sign (\#), ps <.01]. 


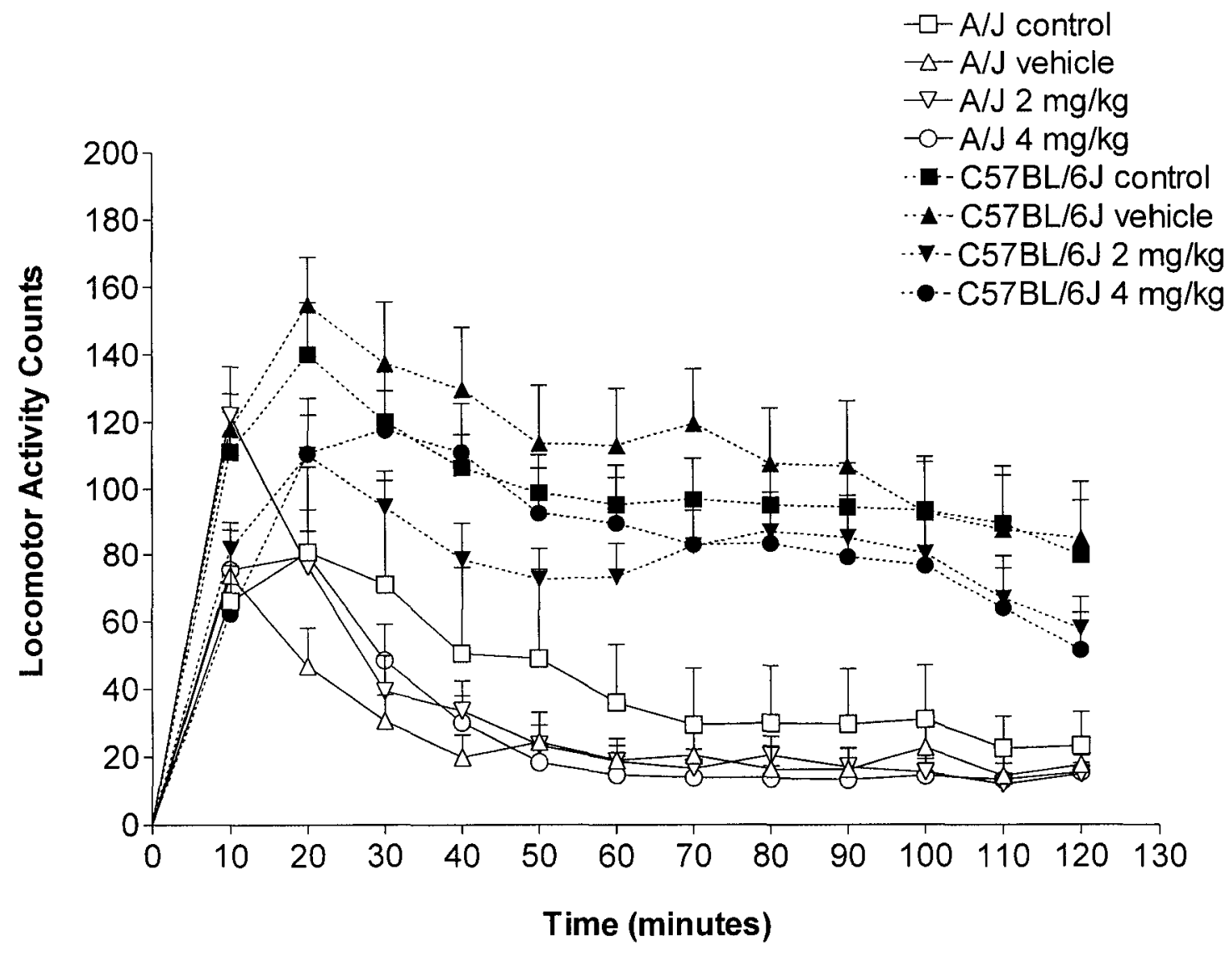

Figure 5. Patterns of amphetamine-induced hyperlocomotion after long-term (22-day) clozapine treatment. Data points represent mean + SEM for locomotor activity counts. Again, the amphetamine response curves are different between the two mouse strains $[p<$ $.0018]$. Treatment effects are only seen within the first 40 minutes of the testing session $[\mathrm{ps}<.05]$. The peaks of locomotor activity occur much sooner compared to testing after four days of clozapine treatment (Figure 3 ). The A/J strain's activity peaks occur between 10-20 minutes, while the C57BL/6J strain's activity peaks occur between 20-30 minutes. 


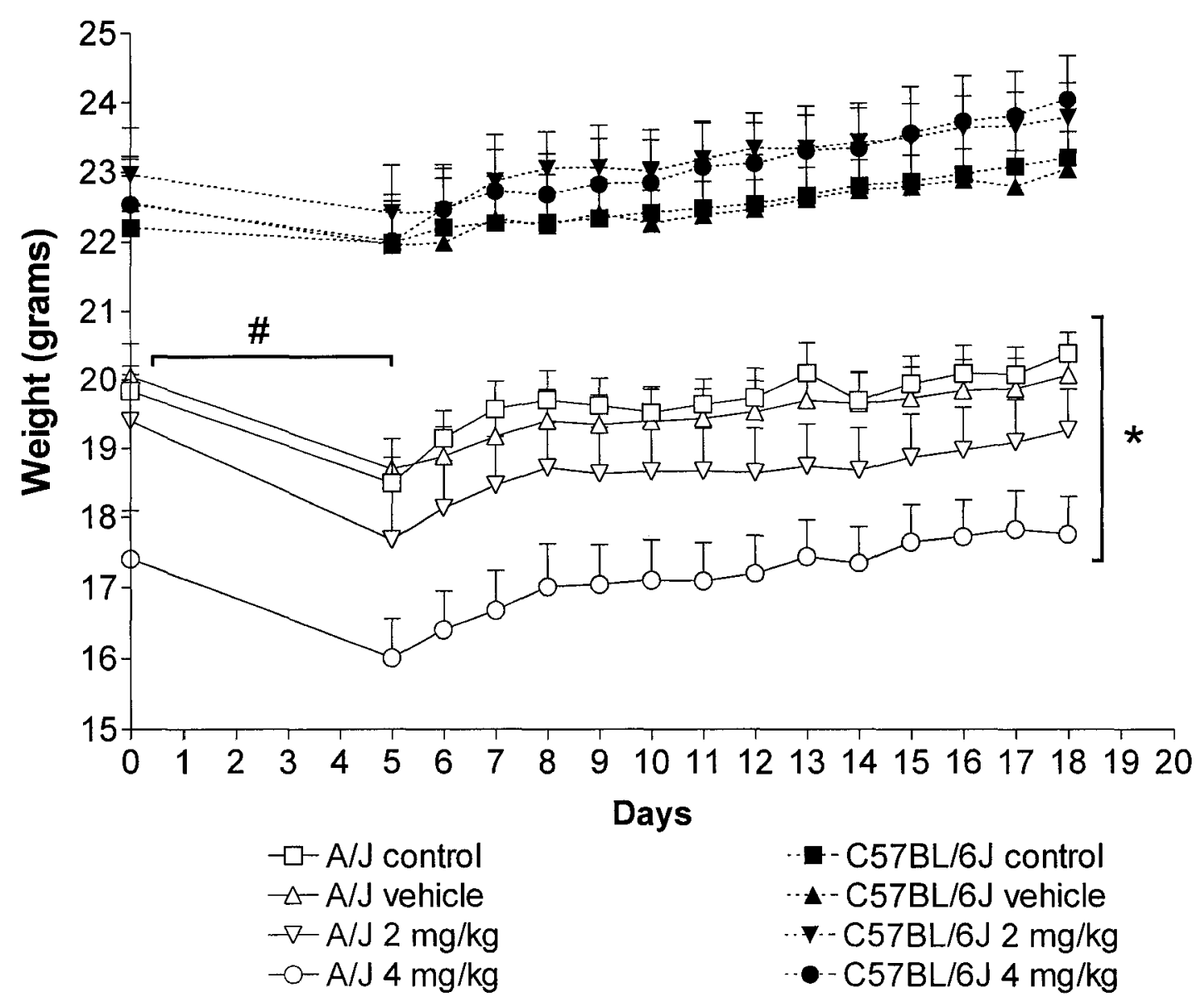

Figure 6. Weight in male $\mathrm{A} / \mathrm{J}$ and $\mathrm{C} 57 \mathrm{BL} / 6 \mathrm{~J}$ mice during long-term treatment with clozapine. Data points represent mean weight + SEM. Mice were untreated (control) or received one intraperitoneal injection of vehicle or clozapine $(2 \mathrm{mg} / \mathrm{kg}$ or $4 \mathrm{mg} / \mathrm{kg})$ per day. All animals were tested for prepulse inhibition on day 3 and for amphetamineinduced locomotion on day 4. After the first four days of injections and behavioral tests, all mice lost weight, but $\mathrm{A} / \mathrm{J}$ mice lost more than $\mathrm{C} 57 \mathrm{BL} / 6 \mathrm{~J}$ mice, regardless of treatment [denoted by a number sign (\#), $\mathrm{p}<.000001$ ]; this weight loss may be due to the stress of the test battery. By day 18 , all mice gained weight relative to their weight at day $5 ; \mathrm{A} / \mathrm{J}$ mice gained more weight than C57BL/6J mice [denoted by an asterisk $(*), \mathrm{p}<.0253$ ]. Clozapine had no significant effect on weight in either strain. 


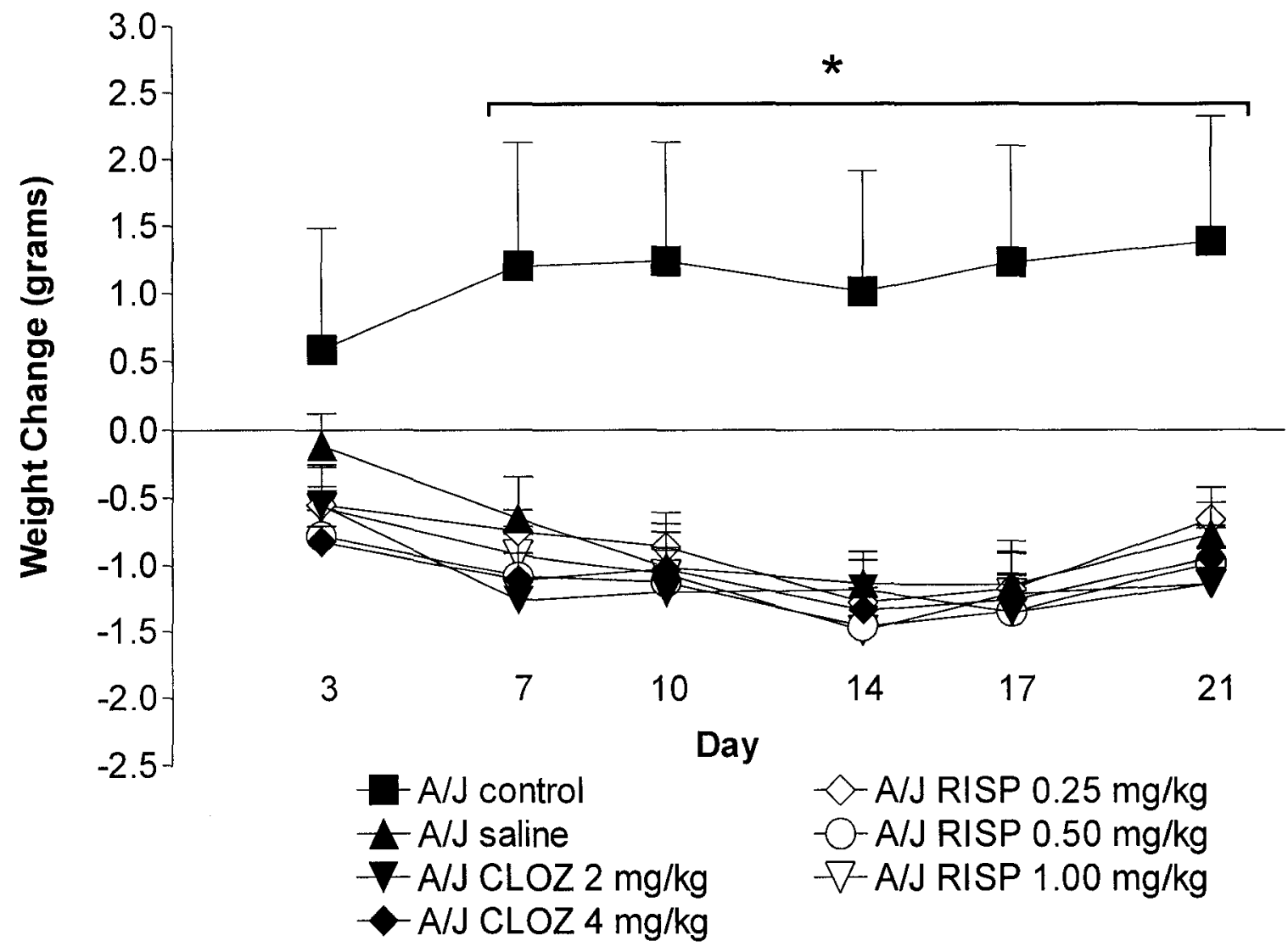

Figure 7. Effects of clozapine and risperidone on cumulative weight changes in female A/J mice. Data points represent mean + SEM for cumulative weight changes relative to weights on day 1 . During the last 14 days of treatment, control mice gained weight, while all other mice receiving any treatment, including saline, lost weight [denoted by a number sign $(\#)$, all ps $<.05]$. 


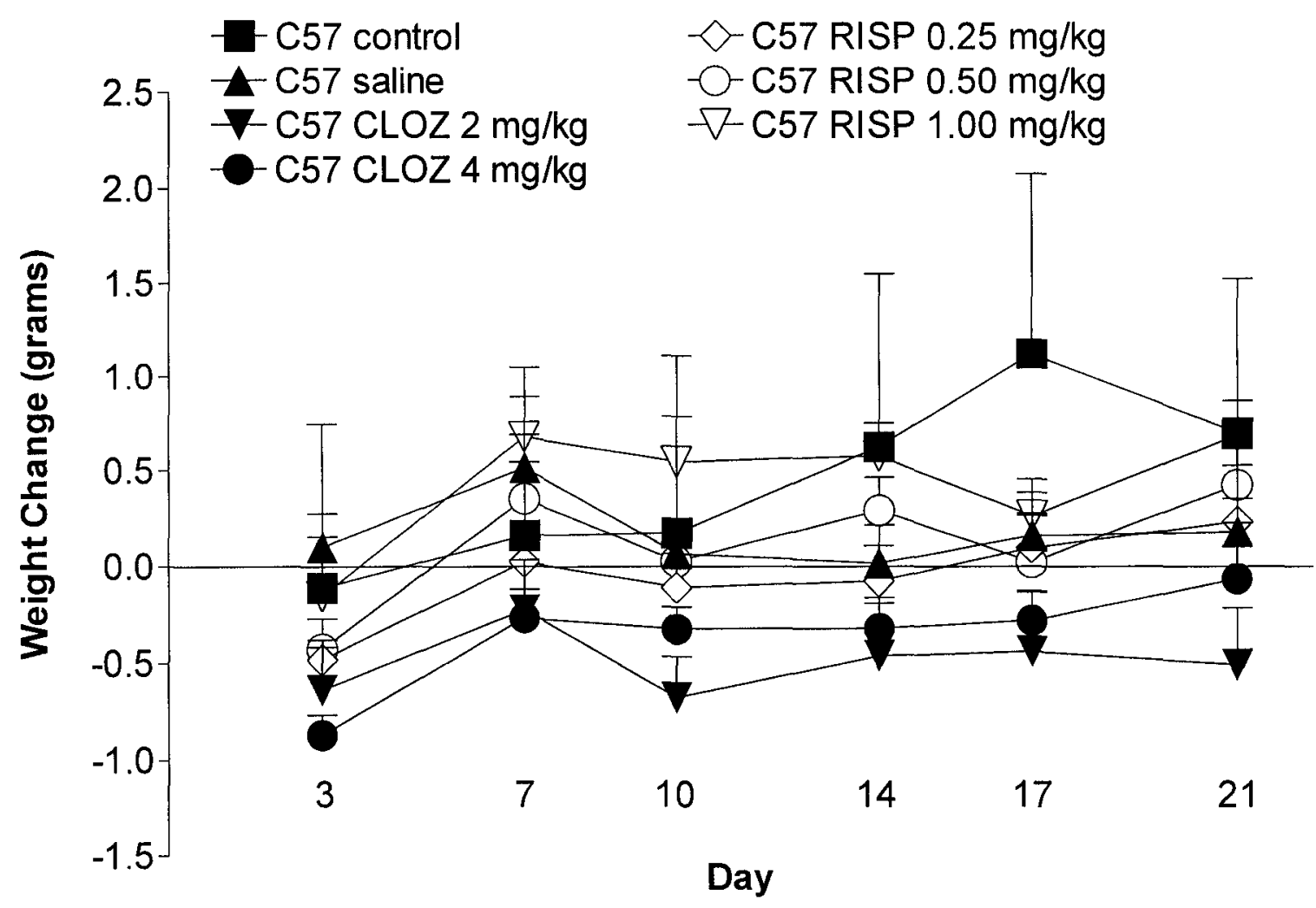

Figure 8. Effects of clozapine and risperidone on cumulative weight changes in female C57BL/6J mice. Data points represent mean + SEM for cumulative weight changes relative to weights on day 1 . 


\section{REFERENCE LIST:}

1. Allison DB, Mentore JL, Heo M, Chandler LP, Cappelleri JC, Infante MC, Weiden PJ (1999) Antipsychotic-induced weight gain: a comprehensive research synthesis. American Journal of Psychiatry 156: 1686-1696.

2. Andersen MP, Pouzet B (2001) Effects of acute versus chronic treatment with typical or atypical antipsychotics on d-amphetamine-induced sensorimotor gating deficits in rats. Psychopharmacology 156: 291-304.

3. Arranz MJ, Munro J, Birkett J, Bolonna A, Mancama D, Sodhi M, Lesch KP, Meyer JFW, Sham P, Collier DA, Murray RM, Kerwin RW (2000) Pharmacogenetic prediction of clozapine response. Lancet 355: 1615-1616.

4. Baptista T, Lacruz A, Meza T, Contreras Q, Delgado C, Mejias MA, Hernandez L (2001) Antipsychotic drugs and obesity: is prolactin involved? Can J Psychiatry 46: 829-834.

5. Baptista T, Parada M, Hernandez L (1987) Long term administration of some antipsychotic drugs increases body weight and feeding in rats. Are D2 dopamine receptors involved? Pharmacol Biochem Behav 27: 399-405.

6. Baptista T, Parada M, Murzi E (1988) Puberty modifies sulpiride effects on body weight in rats. Neuroscience Letters 92: 161-164.

7. Basile VS, Masellis M, McIntyre RS, Meltzer HY, Lieberman JA, Kennedy JL (2001) Genetic dissection of atypical antipsychotic-induced weight gain: novel preliminary data on the pharmacogenetic puzzle. J Clin Psychiatry 62 Suppl 23: 4566. 
8. Benet LZ, Kroetz DL, Sheiner LB (1996) The dynamics of drug absorption, distribution and elimination. In: Goodman \& Gilman's The Pharmacological Basis of Therapeutics (Hardman JG, Limbird LE, eds), pp 7-8. New York: McGraw Hill.

9. Berger N, Vaillancourt C, Boksa P (2000) Genetic factors modulate effects of Csection birth on dopaminergic function in the rat. Neuroreport 11: 639-643.

10. Blin O, Micallef J (2001) Antipsychotic-associated weight gain and clinical outcome parameters. J Clin Psychiatry 62 Suppl 7: 11-21.

11. Braff DL, Geyer MA (1990) Sensorimotor gating and schizophrenia. Human and animal model studies. Arch Gen Psychiatry 47: 181-188.

12. Braff DL, Geyer MA, Swerdlow NR (2001) Human studies of prepulse inhibition of startle: normal subjects, patient groups, and pharmacological studies. Psychopharmacology 156: 234-258.

13. Brenner HD, Dencker SJ, Goldstein MJ, Hubbard JW, Keegan DL, Kruger G, Kulhanek F, Liberman RP, Malm U, Midha KK (1990) Defining treatment refractoriness in schizophrenia. Schizophr Bull 16: 551-561.

14. Bubser M, Koch M (1994) Prepulse inhibition of the acoustic startle response of rats is reduced by 6-hydroxydopamine lesions of the medial prefrontal cortex. Psychopharmacology (Berl) 113: 487-492.

15. Buchanan RW (1995) Clozapine: efficacy and safety. Schizophr Bull 21: 579-591.

16. Bullock AE, Slobe BS, Vázquez V, Collins AC (1997) Inbred mouse strains differ in the regulation of startle and prepulse inhibition of the startle response. Behavioral Neuroscience 111: 1353-1360. 
17. Corbin AE, Meltzer LT, Ninteman FW, Wiley JN, Christoffersen CL, Wustrow DJ, Wise LD, Pugsley TA, Heffner TG (2000) PD 158771, a potential antipsychotic agent with D2/D3 partial agonist and 5-HT(1A) agonist actions. II. Preclinical behavioral effects. Neuropharmacology 39: 1211-1221.

18. Cortese L (2002) New hope in pharmacotherapy for schizophrenia. Hospital Physician 38: 21-28, 50.

19. Depoortere R, Perrault G, Sanger DJ (1997) Potentiation of prepulse inhibition of the startle reflex in rats: pharmacological evaluation of the procedure as a model for detecting antipsychotic activity. Psychopharmacology 132: 366-374.

20. Detterling M, Cascorbi I (2001) Genetic determinants of clozapine-induced agranulocytosis: recent results of HLA subtyping in a non-Jewish Caucasian sample. Archives of General Psychiatry 58: 93-94.

21. Démant P, Hart AAM (1986) Recombinant congenic strains -- a new tool for analyzing genetic traits determined by more than one gene. Immunogenetics 24 : 416-422.

22. El-Khodor BF, Boksa P (1998) Birth insult increases amphetamine-induced behavioral responses in the adult rat. Neuroscience 87: 893-904.

23. Emsley RA, Roberts MC, Rataemane S, Pretorius J, Oosthuizen PP, Turner J, Niehaus DJ, Keyter N, Stein DJ (2002) Ethnicity and treatment response in schizophrenia: a comparison of 3 ethnic groups. J Clin Psychiatry 63: 9-14.

24. Fleischhacker WW, Meise U, Gunther V, Kurz M (1994) Compliance with antipsychotic drug treatment: influence of side effects. Acta Psychiatr Scand 382: 11-15. 
25. Fortin A, Cardon LR, Tam M, Skamene E, Stevenson MM, Gros P (2001a) Identification of a new malaria susceptibility locus (Char4) in recombinant congenic strains of mice. Proc Natl Acad Sci U S A 98: 10793-10798.

26. Fortin A, Diez E, Rochefort D, Laroche L, Malo D, Rouleau GA, Gros P, Skamene E (2001b) Recombinant congenic strains derived from A/J and C57BL/6J: a tool for genetic dissection of complex traits. Genomics 74: 21-35.

27. Frackiewicz EJ, Sramek JJ, Herrera JM, Kurtz NM, Cutler NR (1997) Ethnicity and antipsychotic response. Ann Pharmacother 31: 1360-1369.

28. Freed WJ (1988) The therapeutic latency of neuroleptic drugs and nonspecific postjunctional supersensitivity. Schizophr Bull 14: 269-277.

29. Geyer MA, Krebs-Thomson K, Braff DL, Swerdlow NR (2001) Pharmacological studies of prepulse inhibition models of sensorimotor gating deficits in schizophrenia: a decade in review. Psychopharmacology 156: 117-154.

30. Geyer MA, Swerdlow NR, Mansbach RS, Braff DL (1990) Startle response models of sensorimotor gating and habituation deficits in schizophrenia. Brain Res Bull 25: 485-498.

31. Groot PC, Moen CJA, Dietrich W, Stoye JP, Lander ES, Démant P (1992) The recombinant congenic strains for analysis of multigenic traits: genetic composition. Federation of American Societies for Experimental Biology (FASEB) Journal 6: 2826-2835.

32. Halperin R, Guerin JJ, Jr., Davis KL (1989) Regional differences in the induction of behavioral supersensitivity by prolonged treatment with atypical neuroleptics. Psychopharmacology (Berl) 98: 386-391. 
33. Hoffman DC, Donovan H (1994) D1 and D2 dopamine receptor antagonists reverse prepulse inhibition deficits in an animal model of schizophrenia.

Psychopharmacology 115: 447-453.

34. Hoffman HS, Ison JR (1980) Reflex modification in the domain of startle: I. Some empirical findings and their implications for how the nervous system processes sensory input. Psychol Rev 87: 175-189.

35. Jackson DM, Johansson C, Lindgren LM, Bengston A (1994) Dopamine receptor antagonists block amphetamine and phencyclidine-induced motor stimulation in rats. Pharmacology, Biochemistry, and Behavior 41: 465-471.

36. Jann MW (1991) Clozapine. Pharmacotherapy 11: 179-195.

37. Jann MW, Grimsley SR, Gray EC, Chang WH (1993) Pharmacokinetics and pharmacodynamics of clozapine. Clin Pharmacokinet 24: 161-176.

38. Joober, R., Zarate, J. M., Rouleau, G. A., Skamene, E., and Boksa, P. Provisional mapping of quantitative trait loci modulating the acoustic startle response and prepulse inhibition of acoustic startle. Neuropsychopharmacology. 2002. Ref Type: In Press

39. Karcz-Kubicha M, Wedzony K, Zajaczkowski W, Danysz W (1999) NMDA receptor antagonists acting at the glycineB site in rat models for antipsychotic-like activity. J Neural Transm 106: 1189-1204.

40. Kaur G, Kulkarni SK (2002) Studies on modulation of feeding behavior by atypical antipsychotics in female mice. Prog Neuropsychopharmacol Biol Psychiatry 26: $277-285$. 
41. Kehne JH, Baron BM, Carr AA, Chaney SF, Elands J, Feldman DJ, Frank RA, van Giersbergen PL, McCloskey TC, Johnson MP, McCarty DR, Poirot M, Senyah Y, Siegel BW, Widmaier C (1996) Preclinical characterization of the potential of the putative atypical antipsychotic MDL 100,907 as a potent 5-HT2A antagonist with a favorable CNS safety profile. J Pharmacol Exp Ther 277: 968-981.

42. Kennedy E, Song F, Hunter R, Clarke A, Gilbody S (2000) Risperidone versus typical antipsychotic medication for schizophrenia. Cochrane Database Syst Rev CD000440.

43. Kilts CD (2001) The changing roles and targets for animal models of schizophrenia. Biol Psychiatry 50: 845-855.

44. Lacroix L, Spinelli S, White W, Feldon J (2000) The effects of ibotenic acid lesions of the medial and lateral prefrontal cortex on latent inhibition, prepulse inhibition and amphetamine-induced hyperlocomotion. Neuroscience 97: 459-468.

45. Laruelle M (1998) Imaging dopamine transmission in schizophrenia. A review and meta-analysis. Q J Nucl Med 42: 211-221.

46. Laruelle M, Abi-Dargham A (1999) Dopamine as the wind of the psychotic fire: new evidence from brain imaging studies. J Psychopharmacol 13: 358-371.

47. Laruelle M, Abi-Dargham A, Gil R, Kegeles L, Innis R (1999) Increased dopamine transmission in schizophrenia: relationship to illness phases. Biol Psychiatry 46: 5672.

48. Leadbetter R, Shutty M, Pavalonis D, Vieweg V, Higgins P, Downs M (1992) Clozapine-induced weight gain: prevalence and clinical relevance. American Journal of Psychiatry 149: 68-72. 
49. Li H-S, Borg E (1991) Age-related loss of auditory sensitivity in two mouse genotypes. Acta Otolaryngol 111: 827-834.

50. Lipoldova M, Kosarova M, Zajicova A, Holan V, Hart AA, Krulova M, Demant P (1995) Separation of multiple genes controlling the T-cell proliferative response to IL-2 and anti-CD3 using recombinant congenic strains. Immunogenetics 41: 301 311.

51. Lipska BK, Jaskiw GE, Chrapusta S, Karoum F, Weinberger DR (1992) Ibotenic acid lesion of ventral hippocampus differentially affects dopamine and its metabolites in the nucleus accumbens and prefrontal cortex in the rat. Brain Research 585: 1-6.

52. Lipska BK, Jaskiw GE, Weinberger DR (1993) Postpubertal emergence of hyperresponsiveness to stress and to amphetamine after neonatal excitotoxic hippocampal damage: a potential animal model of schizophrenia.

Neuropsychopharmacology 9: 67-75.

53. Lipska BK, Swerdlow NR, Geyer MA, Jaskiw GE, Braff DL, Weinberger DR (1995) Neonatal excitotoxic hippocampal damage in rats causes post-pubertal changes in prepulse inhibition of startle and its disruption by apomorphine. Psychopharmacology (Berl) 122: 35-43.

54. Martinez ZA, Oostwegel J, Geyer MA, Ellison GD, Swerdlow NR (2000) "Early" and "late" effects of sustained haloperidol on apomorphine- and phencyclidineinduced sensorimotor gating deficits. Neuropsychopharmacology 23: 517-527.

55. Masellis M, Basile V, Meltzer HY, Lieberman JA, Sevy S, Macciardi FM, Cola P, Howard A, Badri F, Nothen MM, Kalow W, Kennedy JL (1998) Serotonin subtype 
2 receptor genes and clinical response to clozapine in schizophrenia patients. Neuropsychopharmacology 19: 123-132.

56. Masellis M, Basile VS, Özedmir V., Meltzer H.Y., Macciardi F.M., Kennedy JL (2000) Pharmacogenetics of antipsychotic treatment: lessons learned from clozapine. Biol Psychiatry 47: 252-266.

57. McCaughran Jr J, Bell J, Hitzemann R (1999) On the relationships of highfrequency hearing loss and cochlear pathology to the acoustic startle response (ASR) and prepulse inhibition of the ASR in the BXD recombinant inbred series. Behavioral Genetics 29: 21-30.

58. McCaughran Jr J, Mahjubi E, Decena E, Hitzemann R (1997) Genetics, haloperidol-induced catalepsy and haloperidol-induced changes in acoustic startle and prepulse inhibition. Psychopharmacology 134: 131-139.

59. Moen CJ, Groot PC, Hart AA, Snoek M, Demant P (1996) Fine mapping of colon tumor susceptibility (Scc) genes in the mouse, different from the genes known to be somatically mutated in colon cancer. Proc Natl Acad Sci U S A 93: 1082-1086.

60. Moen CJ, van der Valk MA, Snoek M, van Zutphen BF, von Deimling O, Hart AA, Demant $P$ (1991) The recombinant congenic strains--a novel genetic tool applied to the study of colon tumor development in the mouse. Mamm Genome 1: 217-227.

61. Olivier B, Leahy C, Mullen T, Paylor R, Groppi VE, Sarnyai Z, Brunner D (2001) The DBA/2J strain and prepulse inhibition of startle: a model system to test antipsychotics? Psychopharmacology 156: 284-290. 
62. Ouagazzal A-M, Jenck F, Moreau J-L (2001) Drug-induced potentiation of prepulse inhibition of acoustic startle reflex in mice: a model for detecting antipsychotic activity? Psychopharmacology 156: 273-283.

63. Paylor R, Crawley JN (1997) Inbred strain differences in prepulse inhibition of the mouse startle response. Psychopharmacology 132: 169-180.

64. Penn JV, Martini J, Radka D (1996) Weight gain associated with risperidone. J Clin Psychopharmacol 16: 259-260.

65. Rietschel M, Naber D, Fimmers R, Möllers H-J, Propping P, Nöthen MM (1997) Efficacy and side-effects of clozapine not associated with variation in the $5-\mathrm{HT}_{2} \mathrm{C}$ receptor. Neuroreport 8: 1999-2003.

66. Rigdon GC, Viik K (1991) Prepulse inhibition as a screening test for potential antipsychotics. Drug Dev Res 23: 91-99.

67. Rigdon GC, Weatherspoon JK (1992) 5-Hydroxytryptamine 1a receptor agonists block prepulse inhibition of acoustic startle reflex. J Pharmacol Exp Ther 263: 486493.

68. Sams-Dodd F (1998) A test of the predictive validity of animal models of schizophrenia based on phencyclidine and D-amphetamine. Neuropsychopharmacology 18: 293-304.

69. Snyder SH (1973) A "model" schizophrenia mediated by catecholamines. American Journal of Psychiatry 130: 61-67.

70. Stanhope KJ, Mirza NR, Bickerdike MJ, Bright JL, Harrington NR, Hesselink MB, Kennett GA, Lightowler S, Sheardown MJ, Syed R, Upton RL, Wadsworth G, 
Weiss SM, Wyatt A (2001) The muscarinic receptor agonist xanomeline has an antipsychotic-like profile in the rat. J Pharmacol Exp Ther 299: 782-792.

71. Swerdlow NR, Braff DL, Taaid N, Geyer MA (1994) Assessing the validity of an animal model of sensorimotor gating deficits in schizophrenic patients. Archives of General Psychiatry 51: 139-154.

72. Swerdlow NR, Geyer MA (1993) Clozapine and haloperidol in an animal model of sensorimotor gating deficits in schizophrenia. Pharmacology, Biochemistry, and Behavior 44: 741-744.

73. Swerdlow NR, Geyer MA (1998) Using an animal model of deficient sensorimotor gating to study the pathophysiology and new treatments of schizophrenia. Schizophrenia Bulletin 24: 285-301.

74. Swerdlow NR, Lipska BK, Weinberger DR, Braff DL, Jaskiw GE, Geyer MA (1995) Increased sensitivity to the sensorimotor gating-disruptive effects of apomorphine after lesions of medial prefrontal cortex or ventral hippocampus in adult rats. Psychopharmacology (Berl) 122: 27-34.

75. Swerdlow NR, Varty GB, Geyer MA (1998) Discrepant findings of clozapine effects on prepulse inhibition of startle: is it the route or the rat? Neuropsychopharmacology 18: 50-56.

76. Taylor DM, McAskill R (2000) Atypical antipsychotics and weight gain -- a systematic review. Acta Psychiatr Scand 101: 416-432.

77. Theisen FM, Cichon S, Linden A, Martin M, Remschmidt H, Hebebrand J (2001) Clozapine and weight gain. Am J Psychiatry 158: 816. 
78. Turbay D, Lieberman J, Alper CA, Delgado JC, Corzo D, Yunis JJ, Yunis EJ (1997) Tumor necrosis factor constellation polymorphism and clozapine-induced agranulocytosis in two different ethnic groups. Blood 89: 4167-4174.

79. Vaillancourt C, Boksa P (1998) Caesarean section birth with general anesthesia increases dopamine-mediated behavior in the adult rat. Neuroreport 9: 2953-2959.

80. van Wezel T, Ruivenkamp CA, Stassen AP, Moen CJ, Demant P (1999) Four new colon cancer susceptibility loci, Scc6 to Scc9 in the mouse. Cancer Res 59: 42164218.

81. Varty GB, Higgins GA (1995) Examination of drug-induced and isolation-induced disruptions of prepulse Inhibition as models to screen antipsychotic drugs. Psychopharmacology 122: 15-26.

82. Wetterling T, Mussigbrodt HE (1999) Weight gain: side effect of atypical neuroleptics? J Clin Psychopharmacol 19: 316-321.

83. Willott JF (1986) Effects of aging, hearing loss, and anatomical location on thresholds of inferior colliculus neurons in $\mathrm{C} 57 \mathrm{Bl} / 6 \mathrm{~J}$ and CBA mice. Journal of Neurophysiology 56: 391-408. 